NBER WORKING PAPER SERIES

\title{
LARGE BANKS AND SMALL FIRM LENDING
}

\author{
Vitaly M. Bord \\ Victoria Ivashina \\ Ryan D. Taliaferro \\ Working Paper 25184 \\ http://www.nber.org/papers/w25184 \\ NATIONAL BUREAU OF ECONOMIC RESEARCH \\ 1050 Massachusetts Avenue \\ Cambridge, MA 02138 \\ October 2018
}

We are grateful for the helpful comments made by Tomasz Piskorski, Kristle Romero Cortes (discussant), Jeremy Stein, Andrew Winton and participants at the American Finance Association (AFA) and European Finance Association (EFA) annual meetings, and seminar participants at the Federal Reserve Bank of Boston and Harvard Business School brown bag seminars. Baker Library Research Services provided assistance with data collection for this project. Data on deposit rates come from RateWatch. The opinions in this paper are the authors' own and do not necessarily reflect those of Acadian Asset Management or the National Bureau of Economic Research. This paper is not investment advice.

At least one co-author has disclosed a financial relationship of potential relevance for this research. Further information is available online at http://www.nber.org/papers/w25184.ack

NBER working papers are circulated for discussion and comment purposes. They have not been peer-reviewed or been subject to the review by the NBER Board of Directors that accompanies official NBER publications.

(C) 2018 by Vitaly M. Bord, Victoria Ivashina, and Ryan D. Taliaferro. All rights reserved. Short sections of text, not to exceed two paragraphs, may be quoted without explicit permission provided that full credit, including (C) notice, is given to the source. 
Large Banks and Small Firm Lending

Vitaly M. Bord, Victoria Ivashina, and Ryan D. Taliaferro

NBER Working Paper No. 25184

October 2018

JEL No. G21

\title{
ABSTRACT
}

We show that since 2007, there was a large and persistent shift in the composition of lenders to small firms. Large banks impacted by the real estate prices collapse systematically contracted their credit to all small firms throughout the U.S.. However, healthy banks expanded their operations and entered new banking markets. The market share gain of these banks was a standard deviation above the long-run historical market share growth and persists for years following the financial crisis. Despite this offsetting expansion, the net effect of the contraction in credit was negative, with lower aggregate credit and deposits growth, and lower entrepreneurial activity through 2015 .

\author{
Vitaly M. Bord \\ Harvard University \\ vbord@hbs.edu \\ Victoria Ivashina \\ Harvard Business School \\ Baker Library 233 \\ Soldiers Field \\ Boston, MA 02163 \\ and NBER \\ vivashina@hbs.edu
}

\author{
Ryan D. Taliaferro \\ Acadian Asset Management \\ 260 Franklin Street \\ Boston, MA 02110 \\ RTaliaferro@Acadian-Asset.com
}




\section{Introduction}

This paper documents a significant and persistent withdrawal of large US banks from small business lending following the Great Financial Crisis. Because large, geographically dispersed banks provide an increasing amount of credit around the world, this withdrawal has dire consequences for small borrowers. However, the full effect on the credit supply to these firms is partially mitigated, as other banks opportunistically expanded their market share. ${ }^{1}$ Importantly, we show that significant changes in the composition of credit providers to small firms persist nearly ten years following the initial shock, driven by merger and acquisition activity which allowed banks to consolidate and make permanent the opportunistic expansion in small business lending origination. These persistent changes result in a decrease in concentration of the small business lending industry, at a time when the overall U.S. banking industry is becoming more concentrated.

Much has been written, particularly in the popular press, regarding the increasing concentration of the US banking industry. ${ }^{2}$ The left Panel of Figure 1 illustrates the well-cited facts: the top banks own a large percentage of all the assets in the industry, and this share has increased during and after the financial crisis. For example, the share of the top 5 banks increased from 33\% in 2006 to $42 \%$ in 2015, while the share of the top 6-20 banks experienced a more modest increase from $17 \%$ in 2006 to $20 \%$ in 2015. By contrast, as the right panel of Figure 1 shows, the concentration of small business lending origination has stayed the same for the top 5 banks-at $32 \%$ - and decreased slightly from $24 \%$ to $22 \%$ for the top $6-20$ banks. $^{3}$ Thus, the persistent credit supply effects we describe below result in major changes in the composition and concentration of small business lending.

To isolate the credit supply effect, we exploit the fact that not all geographical areas were exposed to the 2006-2007 decline in real estate prices. Larger banks tend to be more geographically diversified, and leading up to the crisis, many of these banks operated in areas that had different real estate price evolution. Exposure to losses in one geographical area constitutes a shock to a

\footnotetext{
${ }^{1}$ In normal times, competition for borrowers is hindered by adverse selection, but when banks experience a negative shock, the information gap is reduced, facilitating lender substitution (Dell'Ariccia and Marquez, 2004; Darmouni, 2016).

2 For example, “5 biggest banks now own almost half the industry”, CNBC, April 15, 2015.

3 The concentration in small business lending is lower than in assets because larger banks tend to devote a lower percentage of their assets to small business lending, as we discuss below.
} 
bank’s aggregate activities (Peek and Rosengren 1997; Chava and Purnanandam, 2011; Schnabl, 2012 among others). Thus, for our main results, we consider geographically diversified ("large”) banks with exposure to the real estate shock at the aggregate level, and examine their small business lending activity in counties that did not experience a significant drop in real estate prices. We benchmark these results against other large banks that were not exposed to real estate shocks in their portfolio; the latter, though also geographically dispersed, tend to be banks that are significantly smaller in size.

The core identifying assumption in the analysis is that small business lending is comparable across different banks. This assumption is similar to the one underlying within-borrower analysis that is typically used to identify the effects of credit supply shocks in countries with a centralized credit registry. In Khwaja and Mian (2005) and in much of the literature that builds on this work, there is no comparison of bank characteristics, and aggregate statistics indicate substantial heterogeneity in the bank sample. However, in these studies, the banks are assumed to be comparable in their decisions to lend to the same firm. Similarly, we assume that banks are comparable in making small business loans in a given county. To strengthen the cross-bank comparison, the main control sample of banks includes other geographically diversified banks that did not have exposure to real estate bust. In addition, we show that the findings are generalizable to comparing the largest banks to small, local banks in unaffected areas.

Our data on small business lending come from the Federal Reserve's Community Reinvestment Act (CRA) dataset and cover the period between 2005 and 2015. The advantage of these data is that they provide information about loan origination to US small businesses (loans smaller than \$1 million in size) at the county level for all deposit-gathering institutions except small community banks. Notably, small firms tend to borrow from banks and do so locally (e.g., Petersen and Rajan, 2002; Liberti and Mian, 2009; Agarwal and Hauswald, 2010). So, while the CRA data do not identify individual borrowers, it is feasible to assess the overall economic impact on small creditors using county-level information.

The economic magnitudes are substantial: in unaffected counties - those that do not fall into the top quartile of real estate depreciation between June 2006 and December 2007-large banks exposed to the real estate, on average, cut their small business lending by 25.2 percentage points more, from 2006 to 2008, that similar healthy banks. Over this period, healthy large banks increased their lending to small firms, even as exposed banks slashed their lending. It was not until 
2009 (the trough of the widespread economic recession) that healthy banks' lending to small firms started to drop. After 2009, healthy banks' lending stayed the same and even increased, whereas the lending of exposed banks continued to decline through 2010. This difference between healthy and exposed banks is driven partially by healthy banks' mergers and acquisition (M\&A) activity. However, M\&A does not fully explain the results; exposed banks cut their small business lending by 15.2 percentages more than healthy banks not engaged in expansion through M\&A.

The results on the extensive margin are very similar: following the collapse in real estate prices, exposed banks were more likely than healthy banks to stop operations and close their branches in counties unaffected by the real estate shock. Healthy banks, on the other hand, expanded their operations and entered new markets, particularly ones that were highly competitive or historically difficult to enter.

Reallocation of lending toward healthy banks is also mirrored in the deposit market, as we find that healthy banks substantially expanded their deposit taking activities. ${ }^{4}$ Whereas historically, deposits are sticky, the market share gain of healthy banks following the financial crisis was a standard deviation above the long-run historical average growth in market share. Overall, the deposit reallocation impact among the banks observed during the financial crisis was similar in magnitude to the disruptive effect of geographical deregulation of 1980s. In addition, this expansion of deposits is completely driven by healthy banks' M\&A activity; there is no evidence that other factors, such as high rates, drive the increase in deposits.

Next, we examine the persistence of the changes in the composition of small business lending and deposit-taking activity, and the relationship between the two. We find that the difference between healthy and exposed banks in both lending and deposit-taking persists through 2015. In both cases, the persistence is due to the outperformance of healthy banks engaged in M\&A activity. Importantly, this persistence in lending is not driven just by the mechanical growth from the merger. Healthy banks engaged in M\&A have higher lending growth from 2006 to 2015, relative to exposed banks, even when this lending growth is calculated pro forma to adjust for the mechanical increase from the merger. Thus, healthy banks that acquire new branches and

\footnotetext{
${ }^{4}$ As with loan issuance, in comparing deposit-taking across banks with different characteristics, we assume that all banks offer the same deposit product to a given client (that is, there is no matching between clients and banks). Indeed, in our sample, deposits are insured by the Federal Deposit Insurance Corporation (FDIC), which makes deposits from different banks perfect substitutes.
} 
deposits — and only these banks — are able to make the gains most healthy banks experience in 2006-2008 permanent. These findings are consistent with Mester, Nakamura and Renault (2001), who show that information collection through deposit-taking and borrower monitoring are interlinked and with Gilje, Loutskina, and Strahan (2016), who document the importance of branch networks for lending in markets with contracting frictions, even in the presence of developed and integrated external capital markets.

Finally, we analyze how the change in small business lending is associated with subsequent firm employment and new business creation outcomes. We show that the offsetting expansion and growth by healthy banks does not fully make up for the cutbacks by exposed banks, neither during nor after the financial crisis. Counties with a larger presence of exposed banks experience slower overall growth in both deposits and loans, and these effects persist through $2015 .{ }^{5}$ In addition, these counties also experience higher unemployment, a higher decrease in the number of small business establishments, and a lower rate of new business creation during the financial crisis. The decrease in the number of small business establishments is concentrated in the smallest firmsthose with fewer than 20 employees-and persists through 2014, as does the lower rate of new business creation.

The primary insight of this paper is to show the large and persistent change in the composition of small business lenders: we find that large banks retreat from this segment, leaving a long-lasting economic impact, despite the effect being partially offset by other creditors. Furthermore, we document the importance of M\&A activity and of the growth of deposits and branch networks in making permanent the otherwise temporary and opportunistic expansion in small business lending.

In addition, studying credit availability to small firms is important in and of itself. Small business represents approximately $98 \%$ of all business establishments, $46 \%$ of GDP, and $40 \%$ of employment in the US. ${ }^{6}$ Small firms are bank-dependent, and estimates of the bank supply contraction for large firms (e.g., Ivashina and Scharfstein, 2010) likely understate the corresponding effect on small firms. At the same time, it is important to understand the distinctions between small business and lending and overall bank lending. Although the banking industry

\footnotetext{
${ }^{5}$ These results contrast with those in Greenstone, Mas, and Nguyen (2014), and we elaborate on this difference more in Section 5.

6 “Small Business GDP: Update 2002-2010," Small Business Administration, January 2012. "Small Firms, Employment and Federal Policy,” Congressional Budget Office, March 2012. We are using 100 employees as a threshold.
} 
continues to undergo increasing concentration, the changes in small business lender composition we document result in the opposite effect in small business lending.

More broadly, the findings in this paper contribute to several strands of literature. The evidence for the 2007-2008 period is consistent with the overall severe contraction in credit supply that followed the collapse of real estate prices in the US. Our focus, however, is on small business credit, and specifically, on the impact of the largest banks, as well as the competitive forces that counteract this effect. Recent work by Chen, Hanson, and Stein (2017) reiterate some of our results, emphasizing that the withdrawal of large banks from small lending was particularly pronounced among the top- 4 banks. ${ }^{7}$ We also see our work as contributing to the extensive and growing research on the role of geographically diversified banks in transmitting shocks across different markets. This includes Peek and Rosengren (1997, 2000), as well as more recent papers by Chava and Purnanandam (2011), Schnabl (2012), and Cetorelli and Goldberg (2012).

The outline of the paper is as follows. Section 2 describes the data sources. Section 3 details the identification strategy. Section 4 reports the key empirical results, which demonstrate the propagation of distant shocks through the balance sheets of large banks. Section 5 explores aggregate and long-term effects, and section 6 concludes.

\section{Data sources}

Our main source of data is the Community Reinvestment ACT (CRA) small business lending dataset, filed by all banks with more than $\$ 1$ billion in assets. We complement this with data on bank balance sheets, county deposits, deposit rates, real estate prices, and statistics on the local economy.

\subsection{The CRA Data}

The data on small business loan originations used in our study are collected by the Federal Financial Institutions Examination Council (FFIEC) under the auspices of the Community Reinvestment Act (CRA) enacted by US Congress in 1977. Unlike data collected by the FFIEC under the Home Mortgage Disclosure Act (HMDA), which contain loans and applications for home-related loans, the CRA focuses on small business lending. Small business loans are defined

\footnotetext{
${ }^{7}$ See Chen, Hanson and Stein (2017) for further discussion on the complementarity of their findings.
} 
as loans not exceeding $\$ 1$ million. Specifically, the purpose of the CRA is to "encourage insured depository institutions to help meet the credit needs of the communities where they are chartered." 8 To that end, commercial banks and thrifts regulated by the Office of the Comptroller of the Currency (OCC), the Federal Deposit Insurance Corporation (FDIC), the Federal Reserve System, or, formerly, the Office of Thrift Supervision (OTS), must report annual data on the origination and purchases of small loans.

The CRA data contain a complete and unbiased view of small business loans at filing institutions. As part of their compliance with the CRA, institutions report three types of data. First, institutions must report the aggregate number and amount of loans designated as "community development” lending. Importantly, all filing institutions must also report the aggregate number and amount of all small business loans and small farm loans they originated or acquired during the reporting year. The data distinguish between purchased and originated loans. For the purpose of this study, we only include loan originations. Small business loans - the focus of our study-are loans whose original amounts are $\$ 1$ million or less and that are either commercial or industrial loans or loans secured by non-farm, non-residential real estate. (Small farm loans are loans with original amounts of $\$ 500,000$ or less that are either secured by farmland or used to finance agricultural production. $)^{9}$

The data are disaggregated by size and geographical location. For both small business and small farm loans, institutions are further required to break out the number of loans and total amount originated into the following categories: (i) loans smaller than $\$ 100,000$, (ii) loans between $\$ 100,000$ and $\$ 250,000$, (iii) loans between $\$ 250,000$ and $\$ 1$ million, and (iv) loans issued to very small enterprises with less than $\$ 1$ million in revenues. Institutions report loans by geographical location called "assessment area." Assessment areas are chosen by the banks but must be larger

\footnotetext{
${ }^{8}$ Information about the CRA's purpose and data submissions can be found in the "Guide to CRA Data Collection and Reporting”: http://www.ffiec.gov/cra/guide.htm. Additional information about the details of how institutions file can be found in the "Interagency Q\&A": http://www.ffiec.gov/cra/pdf/2010-4903.pdf."

${ }^{9}$ Small farm loans and loan purchases are small in magnitude relative to small business loan originations, and including them does not qualitatively change our results. On average, small business loan purchases are $4 \%$ of small business loan originations and small farm loans are $8 \%$ of small business loans. Because the number of banks that engage in small farm loans or business loan purchases is small, we are not able to confirm that our results hold for just small farm loans or business loan purchases. Our results remain unchanged when adding small farm loans or business loan purchases to business loan originations.
} 
than a census tract and "consist generally of one or more metropolitan statistical division (MSA/MD) or one or more contiguous political subdivisions, such as counties, cities, or towns.” Filing institutions must report CRA lending for geographies where its branches and ATMs are located, as well as "surrounding geographies in which it has originated or purchased a substantial portion of its loans." ${ }^{10}$ For ease of comparison, we aggregate the data up to the county level.

Only banks above a certain threshold have to file CRA reports, and the assets threshold for reporting institutions increases each year. Notably, prior to 2005, all banks with more than \$250 million in assets, or those with less assets but associated with a bank holding company with more than $\$ 1$ billion in assets, had to file information under the CRA. In 2005 (the beginning of our sample), the size requirement was raised to $\$ 1$ billion. Since then, it has been adjusted slightly each year: in 2007, only institutions with more than $\$ 1.033$ billion in assets had to file, whereas by 2015 , the size threshold rose to $\$ 1.221$ billion.

We exclude thrift institutions from our sample so that we may have consistent and consolidated balance sheet and income statement information at the holding company (BHC) level. Our final sample includes 648 banks; these banks account for $72 \%$ of all bank deposits in 2006. The fact that only large banks have to file might appear restrictive insofar as small firms are more likely to borrow from smaller banks (e.g., Stein, 2002; Berger et al., 2005). However, as of 2006, CRA filers_-banks with more than $\$ 1$ billion in assets_-had on their balance sheets $63 \%$ of all small business lending as reported by all banks in their Call Reports. In sum, the CRA data cover a large fraction of US banks and a large fraction of bank lending to small firms.

CRA data complement the small business and farm lending data reported by institutions in Schedule RC-C of the Consolidated Reports of Condition and Income ("Call Report”). The Call Report data are a stock: they report the total number and amount of all small business and small farm loans outstanding. By contrast, the CRA data are a flow: as of the end of each calendar year, the data give insight on the total number and amount of small business loans originated in that year. In contrast to HMDA data or loan data collected through a credit registry in foreign countries, the limitation of CRA data is that they are aggregated by geographical location and by size, and do not identify individual borrowers. As mentioned earlier, the data cover only loans smaller than $\$ 1$ million in origination size issued by relatively large banks.

\footnotetext{
${ }^{10}$ http://www.ffiec.gov/cra/guide.htm.
} 
Data collected under the CRA is used to assign CRA ratings which the FFIEC takes into account when an institution applies to engage in merger and acquisition (M\&A) activity or to open a new branch. In the context of our study, one could be concerned that an increase in small lending by relatively healthy banks could be a response to an increase in regulatory and public scrutiny or a desire to pursue M\&A more broadly: those banks that can afford it increase lending in counties that were lagging on CRA compliance. The use of a difference in difference approach at the county level gets around these issues.

\subsection{Other Data Sources}

We use five other main data sources:

Banks' balance sheet data: We obtain quarterly bank and bank-holding accounting data from the Federal Reserve. We use data at the bank holding company (BHC) level (FRB form Y9C), or, if a holding company is not available, we use data at the bank level (Call Report level). Throughout the paper, we use the term "bank" to refer to the consolidated entity.

Deposits: We use Summary of Deposits (SOD) data from the FDIC, measured annually as of June $30^{\text {th }}$, to ascertain the deposits of each bank across its branches in each county. (Commercial banks that the CRA are a subset of institutions that file FDIC deposit data.) We aggregate deposits by county to the corresponding bank holding company if the bank holding company exists, and to the corresponding commercial bank if it does not. We also obtain branch-level deposit rate data from RateWatch.

The real estate shock: We obtain county-level real estate price index data from FISERV. FISERV publishes Case-Shiller house price indices using same-house repeated-sales data. Although the data are available at the zip-code level, we use county-level information in correspondence with our data on small business lending.

Local economy: Finally, we use annual county-level demographics data as of 2006 from the Census Bureau and employment and establishment data from the County Business Patterns and Census Business Dynamics Statistics datasets.

\section{Empirical design}

To examine the change in the composition of lenders, we first establish a causal link between banklevel shocks and effect of their propagation on lending more broadly. To do so, we compare the 
lending behavior of banks that were exposed to geographies that suffered severe drops in real estate prices with the behavior of relatively unaffected banks. To identify a supply channel, we examine lending behavior by these two types of banks within areas that were not affected by real estate price shocks. We subsequently examine banks' deposit-taking behavior in an analogous way.

To illustrate our methodology, consider the representative cases of the following two banks in our sample: TCF Financial Corp and Amcore Financial Corp. TCF is a medium-sized regional bank with assets of \$14.3B as of June 2006, and primarily operating in the Midwest-Illinois, Minnesota, Michigan, and Wisconsin. TCF had branches in several areas that were severely affected by the real estate crisis, including $12 \%$ of its deposits in Oakland and Washtenaw Counties, MI which experienced real estate declines of $15 \%$ and $13 \%$, respectively, from June 2006 to December 2007. Because of the size of its presence in these markets, TCF is characterized as "exposed" (to the real estate shock) by our algorithm.

Amcore Financial is also a medium-sized regional bank, with assets of $\$ 5.4 \mathrm{~B}$ as of June 30, 2006. It also serves the Midwest and all of its branches are in Illinois and Wisconsin. However, unlike TCF, Amcore did not have branches in counties that experienced a big drop in real estate prices. The worst performing county where Amcore had branches was Vermillion County, IL, which experienced a 5\% decline in real estate prices, and Amcore had less than 5\% of its deposits located there. Because of this, Amcore is characterized as "healthy" by our algorithm. Since both banks serve the Midwest, they overlap in several counties, including two where the real estate prices did not fall—Cook County, IL and Milwaukee County, WI.

The crux of our identification comes from comparing the deposit-taking and lending activities of exposed banks, such as TCF, with healthy banks, such as Amcore, in counties in which they both operate and in which real estate prices did not plummet. This empirical design requires us to focus on banks that are geographically dispersed. To measure geographical presence, for each bank, we compute the Herfindahl-Hirschman Index (HHI) of deposits across the counties the bank operates in, as of June 30, 2006. That is, for each bank, we calculate the percent of total deposits that are in each county, and the HHI is the sum of the squared percentages for each bank. Our main 
sample is constrained to banks in the lowest quartile of the HHI distribution. ${ }^{11}$ The banks in this sample represent 65\% of all US bank deposits as of 2006.

We define counties affected by the real estate shock as counties in the bottom quartile of the distribution of the change in the Case-Shiller index from the end of the second quarter of 2006, the quarter in which the real estate market reached its peak, to the fourth quarter of 2007, the beginning of the economic recession. Thus, the affected counties are counties with a 2006:Q2-2007:Q4 decline in real estate prices in excess of 2.5\% (an average decline of 10\%). By comparison, the national Case-Shiller index fell by 6.1\% during this period. Since banks in our sample have a broad geographical presence, we calculate each bank's deposit-weighted exposure to the affected counties, and then scale this exposure by the bank's total deposits as of June 30, 2006. By this measure, banks in the bottom quartile are classified as exposed to the real estate shock. ${ }^{12} \mathrm{We}$ classify banks as unaffected or "healthy" otherwise. Exposed banks have an average depositweighted exposure of $-5.7 \%$, as opposed to an exposure of only $-0.2 \%$ for healthy banks. ${ }^{13}$

Deposits are an indirect measure of banks' county-level exposure to real estate shocks. In Figure 1, we validate this measure by looking at aggregate metrics that show that banks we classify as exposed indeed experience substantial distress. First, as compared to unaffected banks, banks classified as exposed sustain a substantially larger increase in real estate loans past due (as a fraction of total loans) starting in 2007. Second, these exposed banks also show a rise in net chargeoffs on real estate loans. Both of these patterns are consistent with high exposure to the real estate shock.

\footnotetext{
${ }^{11}$ This approach is comparable to Cortes (2013), who defines banks as local if more than two-thirds of their deposits are located in the main MSA or county market where they operate. Our definitions characterize as local all banks that are defined as local by Cortes, and approximately $80 \%$ of our local banks are characterized as local by Cortes's definition. Our results are also robust to using a filter the distribution of the number of counties each bank has branches in.

${ }^{12}$ The results are robust to other definitions of healthy and exposed based on terciles or quintiles of the distribution. Defining healthy banks as those in the top two quartiles also does not change our results. Measuring the real estate shock from 2006:Q2 to any period from 2007:Q2 to 2008:Q2 does not change our results. Finally, as discussed further in the robustness section, defining healthy and exposed banks based on the number of affected counties the bank has branches in, or the percent of deposits in affected counties, does not change the results.

${ }^{13}$ Because counties that experienced a larger real estate shock were more likely to be urban and large, by our definitions, the average exposed bank had approximately $47 \%$ of its deposits in affected counties, while the average healthy bank only had $13 \%$ of its deposits in affected counties.
} 
The two lower panels in Figure 1 show evidence for the two mechanisms through which the initial real estate shock led to the contraction in credit supply. The first is capital constraints: the average Tier 1 capital ratio declined for healthy as well as exposed banks, but it sank more, and remained much lower, for exposed banks. Although on paper, even exposed banks had Tier 1 capital ratios higher than the minimum $4 \%$ requirement, there was widespread concern at the time that Tier 1 ratios were not representative of banks' true financial health. ${ }^{14}$ News outlets reported that this anxiety over banks' financial health led regulators to push banks to raise more capital, making sure that their Tier 1 ratios were much higher than the minimum requirements. ${ }^{15}$ As illustrated in the bottom left panel, the sudden rise in banks' Tier 1 ratios in the last quarter of 2008 and in 2009 is consistent with capital injections.

The second mechanism is increased risk of short-term lending. Due to exposed banks' higher charge-offs and falling capital ratios, the risk of short-term lending to these banks increased in both the Federal Funds and repo markets (e.g., Gorton and Metrick, 2012; Afonso, Kovner, and Schoar, 2011). The bottom right panel of Figure 1 shows that both healthy and exposed banks had trouble rolling over their short term federal funds and repo debt as those markets became stressed in late 2007, but the effect was greater for exposed banks.

\section{[FIGURE 1]}

To quantify the credit supply shock due to the real estate price decline the exposed banks experienced, we examine the subsequent lending behavior of healthy and exposed banks. Importantly, we need the clienteles of the banks in our sample to be comparable within the dimensions that we consider: lending to small firms and deposit-taking. This assumption parallels the borrower fixed effect approach typically used to identify effects of credit supply in countries with a centralized credit registry. The papers using this approach, such as Khawaja and Mian (2008), similarly assume banks to be comparable because they lend to the same borrower, and not because their characteristics look the same. The underlying assumption in such an approach is that different banks lend to the same borrower for the same purpose and/or with the same collateral. In

\footnotetext{
${ }^{14}$ For example, the Wall Street Journal pointed out in April 2008 that Citibank and Merrill Lynch had avoided letting certain write-downs impact their income statements and Tier 1 ratios by classifying them as "comprehensive other income.” See “A Way Charges Stay off Bottom Line,” Wall Street Journal, April 21, 2008.

15 "Banks Told: Lend More, Save More; Can They Do Both? Regulators Want to See More Capital, Regardless,” Wall Street Journal, December 26, 2008.
} 
our setting, small business loans originated by different institutions are comparable because they are reported under the auspices of the CRA, enacted "to encourage depository institutions to help meet the credit needs of the communities in which they operate.” Thus, from a policy perspective, these loans are seen as comparable. ${ }^{16}$ This means that a firm's employment is local, but it does not necessarily mean that the demand for the firm's products is local. The concern is that TCF and Amcore Financial, from our earlier example, both lend to small firms in Cook and Milwaukee counties, but TCF lends to exporting firms (i.e., firms with out-of-county demand) and these firms, in turn, might be affected by the out-of-county shock through a drop in demand. To address this possibility, we look at the trends in lending growth up to the real estate shock.

If exposed banks are indeed lending to exporting firms, we would expect not only a differential collapse in lending following the real estate shock, but a differential increase in lending during the boom in real estate prices. In other words, the positive correlation with real estate prices in counties that experience the real estate boom and bust should arise throughout the cycle and not just in the downturn. Figure 2 suggests that this is not the case: the lending patterns from 1996 to 2006 are very similar for both groups, especially in the $\$ 250,000$ to $\$ 1$ million category, which comprises the majority of the value of small business lending done by the banks. We test for trends (displayed beneath the figure) in the pre-crisis period of the figure by regressing the amount of each bank's small business lending (scaled by the 2006 level) on our indicator for healthy banks, a linear time trend, and the interaction of the two, using county fixed effects. The results show that there is no differential time trend between the two groups (the interaction is not statistically significant) and the indicator for a healthy bank is not significant in the period prior to the crisis. ${ }^{17}$

\section{[FIGURE 2]}

There are other alternative explanations, which we discuss in the next section.

The evidence discussed above gives credence to our assumption that the small business lending behavior of exposed and healthy banks is similar, despite the differences these two types of banks may have in their overall characteristics. Table 1 presents summary statistics for our sample. Because the size distribution of US banks is highly skewed, and because the largest banks are more

\footnotetext{
16 http://www.ffiec.gov/cra/history.htm.

${ }^{17}$ Alternatively, we test for trends by including the full 1996-2015 sample, year fixed effects and the interactions between each year indicator and our healthy bank indicator. Prior to 2006, none of the interactions are significant, whereas all the interactions from 2007 to 2014 are positive and significant. We also find no difference in pre-trends when using the yearly percent change, the dependent variable we consider in the rest of the analysis.
} 
likely to operate in many different (urban) areas and thus are more likely to have had exposure to strong real estate price decreases, exposed banks are on average significantly larger than healthy banks. As of the end of the second quarter of 2006, the average exposed bank has 458 branches in 65 counties and assets of $\$ 100.8$ billion, whereas the average healthy bank has 68 branches in 16 counties and assets of $\$ 3.9$ billion. Exposed banks also have other characteristics that are associated with larger US banks such as lower deposits to assets and tier 1 capital ratios and a higher ratio of commercial and industrial loans to assets. This is also consistent with Figure 1.

Despite the differences in overall characteristics, the two types of banks are similar in aggregate loan characteristics and quality. The percentage of real estate lending was similar for the two types of as of 2006, which highlights that our identification strategy comes where the banks operated and extended real estate loans, rather than have from any differences in lending behavior during the 2002-2006 boom. Although the two groups differ in the percentage of loans that are classified as commercial and industrial (C\&I) lending, the percent of small business loans outstanding as a fraction of total loans outstanding is not meaningfully different.

In addition, some of the large disparities seen in Table 1 are due to averages skewed by outliers. Excluding the largest 10 banks drops the average assets of exposed banks to $\$ 19$ billion and narrows the deposits gap from 11 to 7 percentage points. As shown in the robustness tests, our results remain both economically and statistically significant if we exclude the largest banks. However, due to the distribution of bank size, trying to closely match banks by size substantially reduces the economic relevance of the sample.

\section{[TABLE 1]}

\section{Results - Lending}

In this section, we investigate how the exposed banks' exposure to the real estate shock affects their subsequent small business lending behavior. We find that exposed banks cut lending more than healthy banks, and they are more likely to exit a county by closing all branches. On the other hand, healthy banks are more likely to enter new counties. In addition, part, but not all, of the difference between exposed and healthy banks’ lending is driven by healthy banks’ M\&A activity.

We begin the analysis by examining whether exposure to the real estate shock affects the intensive margin of banks' lending in counties unaffected by the shock. Table 2 presents the basic, univariate results and illustrates the marked differences between the two types of banks. In counties 
that did not experience a decline in real estate prices, healthy banks tended to increase their lending from 2006 to 2008 while exposed banks cut theirs. For example, on average, exposed banks extended 15\% fewer loans per county in 2008 than in 2006, whereas unaffected banks increased the number of loans they extended by 1.6\%. Similarly, exposed banks cut their total lending by 9\%, whereas unaffected banks increased their lending by approximately $8 \%$. This pattern is consistent across all loan size categories. Interestingly, the only category in which both types of banks cut their loan originations was lending to firms with revenues of less than \$1 million. Healthy banks cut the number of loans to these firms by $10 \%$, and the loan amount by $4 \%$; exposed firms cut even more, slashing their number of loans to these businesses by $23 \%$ and the loan amount by $14 \%$.

\section{[TABLE 2]}

The results on banks' deposit-taking activities parallel those on small business lending. Despite deposit insurance, county deposits held by exposed banks shrank on average by 10\% between 2006 and 2008 , whereas they grew by $10 \%$ for healthy banks. The distribution is non-normal, but the medians also suggest a similar story: the median percent change in deposits was 3.8\% for exposed banks and 7.7\% for healthy banks. Both healthy and exposed banks seem to have expanded the number of their branches during the 2006 to 2008 period, but healthy banks grew more, opening on average $6.5 \%$ new branches in a county, whereas exposed banks only opened $2 \%$ more branches in each county. As we discuss in the following sections, M\&A activity drives these statistics on the deposits side.

\subsection{Intensive margin: Lending activity 2006-2008}

In Table 3, we look more formally at lending within counties that are unaffected by the direct real estate shock. We estimate regressions of the form:

$$
\Delta L_{i l}=\alpha+\beta \text { Healthy } \operatorname{Bank}_{i}+\gamma X_{i}+\delta l+\varepsilon_{i l} .
$$

$\Delta L_{i l}$ is the change in the logarithm of the amount of small business loans extended by bank $i$ in county $l$ between 2006 and 2008, in millions. ${ }^{18}$ Healthy Banki, our main variable of interest, is an

\footnotetext{
${ }^{18}$ We constrain the analysis to lending in counties in which the bank had a branch since yearly lending to other counties is very volatile. More than $80 \%$ of all small business lending is extended to counties in which the bank has a branch. The loans and deposits data are winsorized at the $0.5 \%$ level.
} 
indicator variable that is equal to 1 for banks classified as healthy and 0 for banks exposed to the real estate shock. $\beta$, the coefficient of interest, can be interpreted as the difference in the percent change in lending from 2006 to 2008 between exposed and healthy banks. ${ }^{19} X_{i}$ is the set of banklevel control variables, and $\delta_{l}$ are county fixed effects. By including county fixed effects, we make sure that we are identifying the impact of being a healthy or an exposed bank on lending within each county.

In specification (1), we find that healthy banks increased their lending more than affected banks. Specification (2) adds county fixed effects $\left(\delta_{l}\right)$ and the lending volume in the country in 2006, while specification (3) also controls for the log of assets to account for the size of the bank. Further, to control for differences in bank strategy, in specification (4) we control for deposits as a fraction of assets, insured deposits as a fraction of total deposits, loans as a fraction of assets, and real estate loans as a fraction of assets. Specification (5) adds controls for the amount of loans that are past due as a fraction of total loans, the amount of net charge-offs (charge-offs minus recoveries) as a fraction of total loans, the Tier 1 ratio, and the amount of asset-backed securities as a fraction of total assets. All bank variables are measured as of June 30, 2006. Specifications (4) and (5) show that our results are not driven by differences in strategy or differences in exposure to real estate or to the securitization market. The control variables generally have the expected signs. The log of loan originations in 2006, which is a measure of the bank's activity in the county, is negative and significant, suggesting that banks with more market power cut lending more. The log of assets becomes significant once we control for other bank balance sheet variables. ${ }^{20}$ Banks with more deposits over assets cut lending less, probably because the healthy dispersed banks are on average smaller and so have higher deposits as a fraction of assets. Standard errors in all specifications are clustered at the bank level. Clustering at both the bank and county levels does not change the standard errors or the significance of the coefficients. In unreported results, we

\footnotetext{
${ }^{19}$ Interpreting a difference in logarithms as a percent change relies on $\mathrm{x}$ being small in the approximation $\log (1+\mathrm{x}) \approx \mathrm{x}$. If $\mathrm{x}$ is large, as it is in some of our observations, the approximation no longer holds. However, using the directly-calculated percent change does not change our results.

${ }^{20}$ This is potentially due to non-linearities in the relationship between bank performance and assets. As mentioned earlier, exposed banks, which performed worse, tend to be larger. But some of the largest exposed banks actually performed better than smaller banks, a result which is potentially explained by government policies such as TARP, which were primarily targeted at large banks. As we discuss below, our results are unchanged when we run the analysis on a constrained sample that removes the largest banks. When we do so, assets impact the change in the amount of loans in a statistically significant way.
} 
show that, as Table 2 suggests, these effects persist across all loan sizes, but are concentrated among loans to firms with revenues of more than $\$ 1$ million. In addition, although we focus on counties unaffected by the real estate shock since our measure of exposure is based on presence in affected counties, the results are very similar when including all counties in the analysis.

The central takeaway is that the difference in lending between healthy and exposed banks is economically and statistically significant, and robust across specifications. On average, the difference in lending between healthy and exposed banks is 25.2 percentage points per county, when including all of our controls. This difference corresponds to an 8.4-percentage-point difference in the weighted average real estate price decline for affected versus unaffected banks. These results are similar to those of Huang and Stephens (2014), who find that a bank's exposure to a $1 \%$ decrease in real estate prices reduces new small business lending by approximately 3-4\%. The large economic magnitude of the decline in lending is also consistent with the results for the same period in Ivashina and Scharfstein (2010).

\section{[TABLE 3]}

Next, we examine whether the difference between healthy and exposed banks is driven by the M\&A activity engaged in by healthy banks. In all specifications of Table 3, we include only institutions that existed as of the end of 2008. Thus, our results are not driven by exposed banks that failed or were bought. However, the sample does include healthy banks that acquired other banks during the 2006-2008 period, and so it is important to examine whether the higher loan growth by healthy banks is due to their M\&A activity. To do so, in Panel B of Table 3, we interact the Healthy bank $k_{i}$ indicator with Engaged in $M \& A_{i l}$, an indicator for the bank engaging in M\&A activity. $^{21}$

Our results show that, although banks that engaged in M\&A grew expansively, even healthy banks that did not engage in M\&A had small business lending growth of approximately 13 percentage points higher than similar exposed banks. This is consistent with the balance sheet channel of shock transmission outlined in Section 2: the difference between exposed and healthy banks comes not just from healthy banks’ expansion through M\&A activity but also through exposed banks’ contraction due to the real estate shock.

\footnotetext{
21 The Engaged in M\&A indicator is defined on a bank-county level. It is equal to 1 if the bank bought another bank operating in the same county during the 2006 to 2008 period, and 0 otherwise.
} 


\subsection{Intensive margin: Lending activity robustness}

Having established that exposed banks cut lending relative to healthy banks, we next perform a wide variety of robustness tests, ruling out that alternative explanation such as differences in subprime exposure, the top 10 banks, or recent entry drive our results. We also show that our results are robust to different definitions of healthy and exposed.

First, in specification (1) of Table 4, we address concerns that our measure of exposure does not take into account subprime real estate prices. During the period we consider, it was mostly the decline in subprime real estate prices that drove banks' losses, whereas our measure of exposure is based on the overall price drop. To take this into account, in specification (1), we rerun our algorithm for classifying banks as exposed, only using counties that had more subprime borrowers. We measure the presence of subprime borrowers by the percentage of 2004-2006 mortgage originations in the Home Mortgage Disclosure Act (HMDA) dataset from 2004 which were classified as "high-priced.” From 2004 to 2008, the Federal Reserve’s Regulation C required lenders to collect and report the spread between the annual percentage rate (APR) on a loan and the yield on Treasury securities of comparable maturity if the spread was "equal to or greater than 3.0 percentage points for a first-lien loan (or 5.0 percentage points for a subordinate-lien loan).”22 These high-priced loans were more likely to be loans to subprime borrowers (Mayer and Pence, 2008). We focus on counties in the top three quartiles of the distribution of the presence of highpriced loans. ${ }^{23}$ The results are very similar in magnitude and suggest that whether the measure of exposure is calculated just using subprime counties or not does not drive our findings.

In addition, we test whether exposure to within-county variation in the presence of subprime borrowers drives our results. Although we constrain our analysis to counties where real estate prices did not crash, counties can cover large geographic areas and it is possible that healthy and

\footnotetext{
22 See “Rules and Regulations”, Board of Governors of the Federal Reserve System, Federal Register, October 24, 2008.

${ }^{23}$ Limiting to counties in the top two quartiles produces qualitatively similar results. The results are also very similar if we define subprime zip codes as those in the top quartile of the presence of high-priced mortgages (similar to the way Mian, Rao, and Sufi (2013) define subprime zip codes using percent of people with FICO score less than 660). We then keep the top three quartiles of counties that have the highest percentage of the population living in subprime zip codes. The results are also robust to using the county level measure of debt to income in 2006, made available by Amir Sufi on his website, as this measure is also highly correlated with the presence of subprime borrowers (Mian, Rao, and Sufi (2013)).
} 
exposed banks differ in the types of within-county areas where they have branches. To address this concern, we create a measure of within-county exposure to subprime areas by calculating, for each bank, the percent of deposits that are in branches located in subprime zip codes. We classify a zip code as subprime if it falls into the top quartile of the distribution of the percent of highpriced HMDA mortgages originated in that zip code between 2004 and 2006. Both exposed and healthy banks have, on average, 15\% of their county deposits in zip codes we classify as subprime, so it is unlikely that differences in the types of neighborhoods where branches are located drive our results.

Next, we examine the importance of the largest banks for our findings. In Specification (2), we exclude the ten largest banks from the analysis; despite a lower number of observations, the results are almost identical. This robustness check mitigates concern that differences in the characteristics of healthy and exposed banks - in particular, the much larger size of exposed banks - drives our findings. As the last 2 columns of Table 1 showed, the characteristics of healthy and exposed banks are much more similar once the ten largest banks are removed. In addition, in unreported results, we perform our analysis on a propensity-score-matched sample of banks. After matching on the bank-level observables we control for in our analysis, and only keeping matches that lie on the support of the propensity score distribution, we obtain a sample of 57 exposed and 40 healthy banks. The results of this section, and most of the subsequent sections, are robust to using this subsample. We do not focus on this subsample due to the small number of observations and subsequent lack of power and economic relevance.

Another concern is that exposed and healthy banks may have different expansionary policies. For example, it could be the case that exposed banks only entered many of the counties we examine in the early to mid-2000s, during the real estate boom and expansionary monetary policy of the period. If these banks over-expanded and decided to scale back, then it would be natural that from 2006 to 2008, they decreased lending in many of the counties that they had just recently entered. In other words, these might be non-core counties for the bank's business, and as such, it might make sense to cut credit in these counties even if there were no changes in demand. Although this mechanism still represents a contraction in credit that propagates into otherwise healthy geographical areas by large dispersed banks, it is a different channel, and it might have different implications for borrowers. To alleviate this concern, in specification (3), we re-estimate our main results using only counties where a bank had branches before 2002. In addition we use only these 
counties when creating the dispersed and exposed variables. The effect remains statistically significant, though lower in magnitude at approximately $15 \%$.

Next, we perform robustness checks to determine that our results are not driven by the precise definition of dispersed and exposed banks. In specification (4), we consider the sample of "large” banks as those in top quartile of the total number of counties, and define "exposed" as the top quartile of the distribution of affected counties. In specification (5), we compare exposed banks with local banks. For methodological reasons, our main control sample is constrained to large, geographically-dispersed banks. However, banks with a large geographical presence may respond to shocks elsewhere (shocks that are different from, but contemporaneous to, the decline in real estate markets), not just in the counties we analyze. In that sense, looking at the small, local banks in unaffected counties as a control group provides insight since these local banks' lending reflects only local conditions. Again, although smaller in magnitude, the coefficients are fairly similar in statistical and economic significance.

Finally, in specification (6), we use a continuous measure of deposit-weighted exposure to the real estate shock across affected counties. Our preferred specification uses the Healthy bank indicator, which is based on the quartiles of the continuous measure, because we are interested in comparing the average healthy and average exposed bank, rather than in the effect of a marginal increase in exposure. Nevertheless, the results of specification (6) shows that the coefficient on the continuous measure is positive and significant, implying that one standard deviation more exposure results in a difference of lending growth of 7.2 percentage points.

\section{[TABLE 4]}

Similar to the parallel trends test for evolution of credit reported in Figure 2, we run placebo tests (unreported) in which we use the difference in lending during the pre-crisis period (e.g., the percent change in lending from 2003 to 2005) as the dependent variable. In these regressions, the Healthy bank $k_{i}$ indicator is not statistically significant, confirming that the difference in lending between healthy and exposed banks arises solely in the pre-crisis period. We also run our results using as the dependent variable the difference between the 2006-2008 and 2004-2006 growth rates, as an alternative way to control for pre-trends.

Finally, it is possible that other events that arose during the early stages of the financial crisis-

rather than the real estate shock-drive our results. One alternative explanation is that the larger banks that were exposed to the real estate shock had greater commitments to off-balance-sheet 
asset-backed commercial paper (ABCP) vehicles. When the ABCP market froze in late 2007, banks that had existing commitments to these vehicles had to provide liquidity and/or credit support to them. As explained in the methodology section, this would have implications for the specific type of channel at work, although we would still be identifying a supply channel. In addition, controlling for the amount of ABCP liquidity and credit commitments as a fraction of assets does not change our results. ${ }^{24}$

\subsection{Extensive margin: County exit and entry, 2006-2008}

Having established that exposure to the real estate shock affected the intensive margin of banks' lending, we next investigate the extensive margin: does exposure to the shock affect whether a bank maintains a lending presence in an area. Although banks engage in small business lending in counties where they do not have branches, on average, more than $85 \%$ of all small business loans (by number and volume) are extended in counties with a branch of the lending bank. Because of this, we proxy for the existence of a bank's lending presence with the existence of a branch in that county.

First, we examine whether exposed banks are more likely to exit a county than unaffected banks. The dependent variable is an indicator equal to 1 if a bank that had branches in the country as of June 2006 no longer has branches in that county as of June 2008, and 0 otherwise. As before, the central explanatory variable is Healthy bank . Specification (1) of Table 5, Panel A, estimates the effect of being a healthy bank on exit from a county, using OLS with county fixed effects. Specifications (2) and (3) use probit, and because probit produces inconsistent estimates when using fixed effects, we instead include county-level controls. These covariates include the change in real estate prices from June 2002 to June 2006 and the change in real estate prices from June 2006 to December 2007; the debt-to-income ratio, the total population, total number of households, household median income, housing density, percent of households below the poverty line, the unemployment rate, and the percentages of households working in finance, construction and real estate, all as of 2006. To provide context for the coefficients we report, in the last line of the table, we provide the marginal effect of Healthy bank, calculated at the means of the other variables.

\footnotetext{
${ }^{24}$ Our results also remain unchanged when controlling for the difference in ABCP liquidity and credit exposure from 2006 to 2008, which is a measure of how much liquidity and credit support banks had to provide during that period.
} 
Reported standard errors are clustered at the bank level; clustering at both the bank and county level or just at the county level produces similar results.

Either estimation approach suggests that healthy, unaffected banks are less likely to exit counties that did not experience a real estate decline. ${ }^{25}$ For example, specification (2) of Panel A suggests that healthy banks are 4 percentage points less likely to exit a county relative to an exposed bank in the same county (compared to an unconditional mean of 10\%). Specification (3) of Panel A drops observations that correspond to exit due to bank failures and mergers and acquisitions (M\&A). The coefficient on Healthy bank $k_{i}$ is much smaller in magnitude because M\&A activity accounts for a large portion of exits. That said, the coefficient is still statistically significant, which implies that exposed banks are more likely to exit a county even if they do not fail and are not acquired.

\section{[TABLE 5]}

In Table 5, Panel B, we examine whether healthy banks are also more likely to enter counties where they did not have branches before 2006. For this analysis, each observation corresponds to a bank-county pair where the bank did not have any branches in the county in 2006, but did have branches in an adjacent county. The dependent variable is an indicator equal to 1 if the bank entered the county in 2007 or 2008, and 0 otherwise. We use probit regression and control for county covariates. As before, the coefficients presented are marginal effects. The coefficient on Healthy $b_{a n k}$ is positive and significant, suggesting that healthy banks were 4.3 percentage points more likely to expand into new counties than exposed banks.

Specifications (2)-(4) further test whether healthy banks are relatively more likely than exposed banks to expand into counties that are traditionally difficult to enter. In specification (2), we measure the difficulty of entry into a county by the number of banks that had entered that county in the previous 10 years. The explanatory variable of interest is the negative of the log of the number of banks that entered the county from 1996 to 2005; a larger value implies that the county is harder to enter. The coefficient on this variable is negative and significant, while the coefficient on its interaction with Healthy bank $k_{i}$ is positive and significant, implying that exposed

\footnotetext{
25 The results are also robust to using a fixed-effects logit.
} 
banks are less likely to expand into hard to enter counties, and healthy banks are relatively more likely to. ${ }^{26}$

Another measure for the difficulty of expanding into a county is concentration, as measured by the HHI of deposits. More concentrated markets may be harder to enter because a few banks control most of the market share and consumers may have longer relationships with one of these banks. Specification (3) supports this hypothesis. The coefficient on the Deposits $\mathrm{HHI}_{\mathrm{l}}$ variable is negative and significant, whereas the coefficient on the interaction between the HHI and Healthy $b_{a n k}$ is positive and significant. Again, exposed banks are less likely to enter into concentrated markets, whereas healthy banks are relatively more likely to.

A final measure of difficulty of entry is an index compiled by Rice and Strahan (2010). This is a state-level index that measures the barriers to cross-state entry that a state imposes on its banking markets. The index uses the values 0 to 4 , which correspond to how many of the following restrictions a state imposes: a minimum age of 3 for institutions of out-of-state acquirers; a ban on de novo branching; a ban on acquisition of individual branches by out-of-state institutions; and a deposit cap of $30 \%$ for each institution. In specification (4), we use this variable as a proxy for difficulty of entry and restrict the observations to the set of out-of-state counties that each bank can expand into. As expected, the coefficient on this variable is negative and significant, but the interaction with Healthy bank $k_{i}$ is positive and significant. Exposed banks are less likely to enter counties in states with restrictions, but healthy banks are relatively more like to do so. Note that, in specifications (3) and (4), the coefficient on Healthy bank is positive, but no longer significant. This implies that healthy banks do not expand more everywhere, but instead focus on counties which they otherwise would have trouble entering.

As with the results on county exit in Panel A, the findings of Panel B are affected, but not completely driven, by healthy banks that expand by buying other banks. In Table A1 of the Appendix, we repeat the analysis of Panel B of Table 5 after removing observations hat correspond to M\&A activity. The results show that even healthy banks not engaged in M\&A were more likely to enter new counties, relative to exposed banks. ${ }^{27}$

\footnotetext{
${ }^{26}$ The marginal effects reported in the last line of the table take into account the relationship between the Healthy bank indicator an the interaction terms.

${ }^{27}$ The results are similar using a triple interaction with the Engaged in $M \& A$ indicator.
} 


\section{Results - Deposits, Mergers, and Persistence}

In the previous section, we showed that healthy banks outpace exposed banks in the intensive margin of increasing loans, as well as the extensive margin of entry and exit. These results are consistent with the balance sheet channel of shock transmission; exposed banks contract their lending more than healthy banks because of the real estate shock. In addition, Tables 3 and 5 also show that M\&A activity by healthy banks plays a role in their outperformance.

In this section, we examine whether healthy banks also outperform exposed banks in their deposit growth. We find that healthy banks' deposits do grow faster, and that this is driven completely by M\&A activity. Further, healthy banks that grow through acquisition have higher lending growth than exposed banks in the same county, in the long-term, even after adjusting for the mechanical growth from the merger.

\subsection{Intensive margin: Branches and Deposits, 2006-2008}

Having established that healthy banks cut lending less, and expand their lending presence more, than exposed banks in unaffected counties, we next examine whether banks behave similarly with respect to deposit-taking. To do so, we repeat the analysis of specification (5) of Table 3 using the change in the log of deposits as the dependent variable. Specification (1) of Table 6 shows that the healthy bank indicator is again positive and significant, implying that healthy banks increase their deposits by 7 percentage points more than exposed banks. In comparison to the effect on lending, this might seem small. However, deposits - especially retail deposits - tend to be very sticky, and capturing new deposits may be harder than capturing new borrowers. Note that since this specification limits the sample to counties in which the bank had a branch both in 2006 and 2008, the inter-county expansion established in Table 5 does not explain these results.

\section{[TABLE 6]}

Next, we examine whether, in parallel with increasing their deposits, healthy banks also increase their number of branches more than exposed banks. In specification (2) of Table 6, the dependent variable is the percent change from 2006 to 2008 in the number of branches. The coefficient on the Healthy Bank indicator Healthy bank $k_{i}$ is positive and significant, and suggests that healthy banks increased their number of branches by 6 percentage points more than exposed 
banks. However, the distribution of the percent change of branches is highly skewed; the median change in the number of branches is 0 for both types of banks.

To ensure that a few outliers do not drive our results, in specification (3) we replace the dependent variable with an indicator variable that is equal to 1 if the number of branches increased, -1 if it decreased, and 0 if it stayed the same. We run this regression using an ordered probit model, and again control for county covariates rather than county fixed effect. As before, standard errors are clustered at the bank level, but clustering at both the bank and county levels produces similar results. Our results remain strong and statistically significant: healthy banks are more likely to expand their number of branches in the counties they are already in. These results are robust to excluding observations corresponding to merger and acquisition activity.

In specification (4), we investigate whether this increase in branches can fully explain the increase in branch deposits. Using deposits per branch as the dependent variable, we find no difference between healthy and exposed banks, suggesting that healthy bank grow their deposit bases mainly through new branches.

Finally, we examine the economic significance of the increase in deposits by large banks. In specification (5), we consider the change in the deposit market share as the dependent variable. ${ }^{28}$ Our definition of market share, as in Table 3, is holistic and captures both entries and exits. The healthy bank indicator Healthy bank $k_{i}$ is positive and significant at the $1 \%$ level, which suggests that, relative to exposed banks in the same county, healthy banks increase their market share of deposits in the county. The estimate of a difference of 2.5 percentage points is economically significant within the historical context. Using deposit data from 1994 to 2006, we estimate that during this time period, the average market share change over any two year period is a decrease of 0.06 percentage points (after de-meaning by year and by county, consistent with our regressions). ${ }^{29}$ The standard deviation is approximately 2 percentage points. Thus, the difference between healthy and exposed banks of 2.5 percentage points is larger than a one-standard-deviation difference in deposit market share. Similarly, Strahan (2003) finds that post-geographical deregulation, small banks, in aggregate, lost $2 \%$ of their deposits share as a result of increased competition. This

\footnotetext{
${ }^{28}$ For ease of interpretation, we use the change in market shares rather than the percent change. We also do not control for loans or deposits as of 2006 because that would limit our sample to those bank-county pairs in which the bank had branches in 2006.

${ }^{29}$ We consider a change over two years so as to be comparable with our main analysis for the two-year period of 2006-2008.
} 
implies that the increase in the market share for the average healthy bank, relative to an exposed bank, is comparable to the impact of geographical deregulation.

Next, we examine why healthy banks expanded their deposits. One possible explanation is M\&A activity; it may be that the growth in deposits we document in Panel A of Table 6 reflects growth by healthy banks through acquisitions. An alternative explanation is that healthy banks were able to offer lower deposit rates, relative to exposed banks, to attract deposits.

First, in Panel B of Table 6, we rerun the analysis of Panel A, again interacting the Healthy $b_{a n k}$ indicator with the Engaged in $M \& A_{i l}$ indicator. In column 1, we find that the increase in deposit growth is driven mainly by healthy banks that expanded through M\&A. Healthy banks not engaged in M\&A see no increase in deposits, relative to exposed banks. In columns 2 and 3, we re-run columns 2 and 3 of Panel A and find that the increase in branches is similarly driven by M\&A activity. As is expected, the growth in deposits per branch is not driven by M\&A activity, since there is no difference between healthy and exposed banks. Finally, the increase in market share by healthy banks is also driven mainly by acquisitions. This is not surprising, as deposits are thought to be sticky, and it is difficult for a bank to capture deposits from its competitors simply through price competition.

Next, we rule out explicitly that healthy banks grew their deposits because they were able to offer lower deposit rates relative to exposed banks. In Table A2 of the Appendix, we use branchlevel deposit rate data from RateWatch, and re-estimate specification (3) of Table 5 using the change in deposit rates from 2006 to 2008 as the dependent variable. ${ }^{30}$ We find no difference in the change in rates from 2006 to 2008 between our two groups of banks, for accounts with a balance of $\$ 10,000^{31}$. We consider both money market and CD rates, and the results on other types of accounts such as savings and interest checking accounts, are similar. ${ }^{32}$ Moreover, rates on money market and short-term CD accounts for accounts of more than $\$ 100,000$ are in fact lower healthy banks. Thus, it is unlikely that healthy banks increased their deposits because short-term, uninsured accounts, which are more likely to run, flocked to lower rates. If anything, it was

\footnotetext{
${ }^{30}$ For each bank, we obtain the mean change in deposit rates at the county level (across all branches in that county) and use this as the dependent variable. Using the median as the dependent variable does not change our results.

${ }^{31}$ Deposit rates schedules are tiered and tiers vary by banks. RateWatch provides the rates corresponding to accounts with a specific balance such as \$10,000, \$100,000, and so on.

32 These are the accounts with the most data in RateWatch and have been used in prior literature as a proxy for the deposit rates a bank is able to offer (e.g., Drechsler, Savov, Schnabl, 2015).
} 
exposed banks that offered relatively higher rates on large short-term accounts, in an effort to acquire more deposit funding at a time when overnight repo and federal funds were becoming more stressed (Afonso, Kovner and Schoar 2011).

Overall, we find that healthy banks have higher growth in both small business loans and deposits. Their relative outperformance in loans is driven by both by exposed banks' exposure to the real estate shock, and by expansion through M\&A activity. By contrast, the relative growth in deposits is driven purely by expansion through M\&A. In the next section, we examine how these two mechanisms effect the persistence of the results.

\subsection{Persistence of the Results: 2006-2015}

In this section, we show that the changes in market structure we document persisted in the longterm and did not subside after the period of turmoil from 2006 to 2008. We also find that the higher growth in both deposits and loans by healthy banks is driven by mergers and acquisitions. By expanding their deposit base, healthy banks were able to permanently expand their small business loan originations as well. Note that although isolating the long-term impact of the real estate shock is hard due to general upheaval in the financial markets as well as policy interventions, this fact should make it more difficult for us to find persistent changes in the market structure.

Table 7 examines the persistence of the differences between exposed and healthy banks. In Panel A, the dependent variable is the change from 2006 to 2015 in the variable of interest. In specifications (1) and (2), the dependent variables are the percent change in small business originations and the change in the market share of small business loan originations, respectively. The coefficient on Healthy bank is positive and significant in both regressions, suggesting that healthy banks extend more loans and capture more of the loan origination market for exposed banks. In specifications (3) and (4), the dependent variables are for deposits rather than small business loans. In both cases, healthy banks increase their market shares more than exposed banks,

and the difference is both statistically and economically significant. The change in market shares from 2006 to 2015 is 10.9 percentage points higher for healthy banks in lending, and 4.0 percentage points higher in deposits.

\section{[TABLE 7]}

Next, we address the question of why the difference between healthy and exposed banks continues to persist. The mechanism discussed in Section 2 concerns the effect of the real estate 
shock on exposed banks' capital and thus their ability to lend. However, as the real estate market and exposed banks' capital positions recover, lending should also recover and the difference between healthy and exposed banks should subside.

One reason this does not happen is M\&A activity. As we documented in Panel B of Tables 3 and 6, healthy banks engaged in M\&A explain part of the difference in lending growth and all of the difference in deposit growth between healthy and exposed banks in the 2006 to 2008 period. In Panel B of Table 7, we repeat the analysis of Panel B of Table 3, interacting the Healthy bank indicator with the Engaged in $M \& A_{i l}$ indicator. In column 1, the dependent variable is the growth in small business loan origination from 2006 to 2015, and in column 3, the dependent variable is the growth in deposits. In both cases, the persistence of the difference is driven by banks that engaged in acquisitions.

Further, we test whether the persistent effects we document in Panel A are explained completely by the compositional effects of acquisition by examining pro forma lending and deposits. To do so, we adjust the small business loans and deposits for acquiring banks by adding in the values of the target bank prior to the acquisition. ${ }^{33}$ In column 2 of Panel B, we use as the dependent variable the pro forma growth in small business lending. The coefficient on Healthy bank $k_{i}$ is positive and significant, which suggests that healthy banks that engaged in M\&A expansion grew their small business lending, even adjusting for the lending of the institution they bought. In column 4, we use as the dependent variable the pro forma growth in deposits, and the coefficient on Healthy banki is not significant.

Taken together, the results in Panels A and B suggest an important role of deposit acquisition for a bank's ability to opportunistically capture market share during times of crisis. Although all healthy banks have higher growth in lending during the crisis period of 2006-2008, only those that - through acquisitions - capture deposits are able to make these gains permanent. In unreported results, we show that consistent with this interpretation, healthy banks that enter new counties (not through M\&A activity) grow their lending faster than existing healthy banks in these counties. $^{34}$

\footnotetext{
${ }^{33}$ We remove observations corresponding to institutions that acquired banks that do not file CRA data, since these cannot be properly adjusted.

${ }^{34}$ Although the number of observations is low, these results are consistent with our main findings. Results are available upon request.
} 
It may also be that other factors limit exposed banks' ability to grow their lending more and mitigate the difference with healthy banks. For example, it is possible that post-crisis regulation, which targeted larger banks, which tend to be exposed banks, puts additional restrictions on bank lending. In unreported results, we find no evidence for this view. As Figure A1 shows, banks with more than $\$ 100$ billion, which had to complete the Supervisor Capital Assessment Program (SCAP) stress tests in 2009, 2011, 2012 and 2013, experienced similar growth in lending after 2010 as banks with between $\$ 10$ billion and $\$ 100$ billion in assets, which d under this regulation.

\section{Economic impact of the effects}

In the previous sections, we examined the differences between healthy and exposed banks in their lending and deposit-taking behavior, and the persistence of these results. Next, we investigate the overall effect of the presence of exposed banks on a county's local economic conditions.

First, we test whether the opportunistic expansion by healthy banks overcomes the decrease in lending by exposed banks. The dependent variables in specifications (1)-(4) of Table 8, Panel A are calculated as aggregates across all healthy banks in a county for the 2006 to 2008 period. The main independent variable of interest is Exposed countyl, the indicator variable for whether a county is exposed to the real estate shock through the presence of branches of affected banks. ${ }^{35}$ Consistent with our conclusions in the preceding sections, the aggregate growth in both loans and deposits of healthy banks is higher in counties with a larger presence of exposed banks. The overall market share of healthy banks also increases more in these counties. In specifications (5)-(6), the dependent variables are total loan and deposit growth across all banks in the county. The results indicate that although healthy banks increase lending and deposits more in areas that have been further exposed to the shock, they do not fully make up for the impact of the shock. Counties with a higher presence of exposed banks had loan growth of 9 percentage points less, and deposit growth of 2.5 percentage points less, than similar counties that were not exposed to the shock. Specification (7) tests whether a county's exposure to the real estate shock affects its concentration, as measured by the deposit HHI. Although the effect is negative, it is not significant. Since we

\footnotetext{
${ }^{35}$ Consistent with prior definitions, Exposed county equals 1 for counties in the top quartile of exposure, calculated as the deposit-weighted exposure measure across banks in the county.
} 
have shown that healthy banks are more likely to enter new and concentrated markets, one might expect the deposit HHI to decrease more in the long run as new entrants gain market share.

\section{[TABLE 8]}

Next, we examine the long-run aggregate effects. Table 8, Panel B replicates Panel A, but uses the change from 2006 to 2015 for all dependent variables. The results are very similar to those of Panel A. Notably, it appears that in the long run, the deposit concentration in exposed counties decreases, as healthy banks enter new, concentrated markets and begin to grow their market shares.

As with the results in previous tables, although the coefficients in this table appear to be small in magnitude, they are economically significant in the historical context. For example, specification (4) of Panel B shows that between 2006 and 2015, healthy banks in exposed counties grew their aggregate market share by 9.8 percentage points more than in other counties. By comparison, Jayaratne and Strahan (1997) find that high-profit banks increase their market shares by 6.7 percentage points in the 6 years following geographic deregulation, relative to a comparable 6 years pre-deregulation. ${ }^{36}$ Similarly, Strahan (2003) shows that HHI decreases by 76 points in the post-deregulation period, which is generally consistent with the results of specifications (7) of Panels A and B.

Finally, we examine whether these differences in lending and deposit-taking have an effect on the real economy. Using the Census County Business Patterns (CBP) dataset, we examine how employment and of the number of operating establishments differ between counties with and without a large presence of exposed banks. ${ }^{37}$ In essence, we rerun the analysis of Table 8 using changes in employment and number of firms as the dependent variables. Because the recession did not start until the end of 2007 and changes in firm employment lagged the changes in small business lending, we use the period from 2007-2009 instead of 2006-2008 in our analysis.

In specification (1) of Panel A of table 9, we use the percent change in employment as the dependent variable. Specification (2) uses the percent change in the total number of establishments. We then disaggregate the change in all establishments into the percent change in establishments with 1-19 workers (specification (3)), 20-49 workers (specification (4)), and more than 50 workers (specification (5)). The first specification shows that there is a statistically significant difference

\footnotetext{
36 The percentage change in deposits from 2006-2012, a comparable 6 years, is 7.4 percentage points.

${ }^{37}$ Unfortunately, the CBP has data for county employment, and number of establishments split by firm size, but not employment split by firm size.
} 
in the change in county employment between exposed and unexposed counties. On average, the decrease in employment is 1.5 percentage points higher in magnitude for exposed counties than unexposed counties. Considering that the total drop in employment from 2007 to 2009 was 7\%, this is an economically significant difference. The second specification shows a similar difference in the number of establishments: exposed counties explain a 1 percentage-point higher drop in number of establishments during the time period. The next three columns of the table show that this decline in the number of establishments mainly comes from smaller firms with fewer than 50 employees, as there is no difference between exposed counties and non-exposed counties in the number of establishments with more than 50 employees. This is intuitive since our exposed county variable captures the presence of banks that decreased small business lending and this type of funding is probably less important for larger firms. The last column shows that this change in the number of small businesses is driven by less business creation in exposed counties. ${ }^{38}$ Exposed counties experience less new firm creation, as a percentage of total firms, relative to counties with a smaller presence of exposed banks.

\section{[TABLE 9]}

Panel B of Table 9 repeats the analysis for the 2007 to 2014 time period. ${ }^{39}$ The results show that due to the presence of exposed banks, exposed counties experience a higher drop in the number of small businesses, which lasts through 2014. This effect seems to only be persistent for the smallest firms, those with fewer than 20 employees. Firms with more than 20 employees recover much faster after 2010. Again, the last column shows that new firm creation is lower in exposed counties.

Our results contrast with those of Greenstone, Mas, and Nguyen (2014), who find that while the decrease in small business lending has a statistically significant impact on employment, the effect is not economically meaningful. One reason for this difference comes from the fact that Greenstone, Mas, and Nguyen use a subsample of small business lending data from the CRA: lending to firms with less than $\$ 1$ million in revenues. This subsample comprises $45 \%$ of all small business lending originated in 2005 (and 48\% of the number of loans originated). In terms of

\footnotetext{
${ }^{38}$ Data on firm births come from the Census Business Dynamics Statistics.

${ }^{39}$ The latest CBP data is as of the end of 2014 so we cannot examine the period ending in 2015 as we do in our other tables. The latest data on Business Dynamics is as of 2013.
} 
employment, to match this data to the US Census Longitudinal Business Database (LBD), Greenstone, Mas, and Nguyen (2014) consider firms with less than \$1 million in revenues to be equivalent to firms with fewer than 20 employees. ${ }^{40}$ Firms with fewer than 20 employees represent approximately 18\% of all employment. The Small Business Administration (SBA) generally classifies as "small" firms with fewer than 500 employees (the average small firm in the SBA sample has annual revenues of \$14 million), and firms with fewer than 500 employees represent about $55 \%$ of all employment. Thus, although the result for the subsample of very small firms is interesting, the SBA definition makes an argument for looking at the full CRA sample, especially when considering broader economic implications.

\section{Final remarks}

Between 2008 and 2010, US unemployment rose to the highest levels in thirty years, and GDP per capita fell by 3\% in a single year. While these adverse outcomes were widely felt across the economy, their causes were more localized. We use this heterogeneity and show that banks affected by a real estate shock in their portfolio substantially reduce their lending in local markets unaffected by the shock, relative to less exposed banks in the same markets. Further, we find that exposed banks were more likely to exit an unaffected market by closing all branches there. However, in parallel, healthy banks used their stronger balance sheets to enter new markets and to expand their activities in both lending and deposit-taking in existing markets. These gains in market shares remain in the long run and are comparable in magnitude to changes resulting from the geographic deregulation of the US banking sector.

The changes in lender composition in the small business lending persist in the decade following the Great Financial Crisis. Overall, while there had been an unambiguous increase in concentration of the banking sector in the U.S., market concentration among the lenders to small business had been decreasing. However, counties with a larger presence of exposed banks experience slower overall growth in both deposits and loans, and these effects persist through 2015. In addition, these counties also experience negative real effects.

\footnotetext{
${ }^{40}$ It is possible that some firms with fewer than 20 employees receive small business loans but have more than $\$ 1$ million in revenues. If that is the case, the effect of the decline in lending supply on their employment would not be captured when only considering loan supply for loans to firms of less than \$1 million in revenues.
} 


\section{References}

Agarwal, S., and R. Hauswald, 2010, “Distance and Private Information in Lending,” Review of Financial Studies 23, 2757-2788.

Afonso, G., A. Kovner, and A. Schoar, 2011, "Stresssed, Not Frozen: The Federal Funds Market in the Financial Crisis,” Journal of Finance 66, 1109-1139.

Becker, B., and V. Ivashina, 2014, “Cyclicality of Credit Supply: Firm Level Evidence,” Journal of Monetary Economics 62: 76-93.

Berger, A., N. Miller, M. Petersen, R. Rajan, and J. Stein, 2005, "Does Function Follow Organizational Form? Evidence from the Lending Practices of Large and Small Banks,” Journal of Financial Economics 76: 237-269.

Cetorelli, N., and L. Goldberg, 2012, "Banking Globalization and Monetary Transmission,” Journal of Finance 67, 1811-1843.

Chava, S., and A. Purnanandam, 2011, "The Effect of Banking Crisis on Bank-Dependent Borrowers,” Journal of Financial Economics 99, 116-135.

Chen, B., S. Hanson, and J. Stein, 2017, “The Decline of Big-Bank Lending to Small Business: Dynamic Impacts on Local Credit and Labor Markets,” NBER Working Paper.

Cortes, K. R., 2013, “Rebuilding after Disaster Strikes: How Local Lenders Aid in the Recovery,” Federal Reserve Bank of Cleveland Working Paper.

Darmouni, O., 2016, “Estimating Information Frictions in Sticky Relationships,” Working paper.

Dell'Ariccia, G. and R. Marquez, 2004, “Information and Bank Credit Allocation,” Journal of Financial Economics 72, 185-214.

Drechsler, I., A. Savov, and P. Schanbl, 2015, “The Deposits Channel of Monetary Policy,” Working Paper.

Gilje, E.P., E.Loustkina, and P. Strahan, 2016, "Exporting Liquidity: Branch Banking and Financial Integration,” Journal of Finance 71, 1159-1184.

Gorton, G. and A. Metrick, 2012, "Securitized Banking and the Run on Repo," Journal of Financial Economics 104, 425-451.

Greenstone, M., A. Mas, and H. L. Nguyen, 2014, "Do Credit Market Shocks affect the Real Economy? Quasi-Experimental Evidence from the Great Recession and 'Normal' Economic Times,” Working Paper.

Huang, H. and E. Stephens, 2014, "From Housing Bust to Credit Crunch: Evidence from Small Business Loans,” Canadian Journal of Economics, Forthcoming.

Ivashina, V. and D. Scharfstein, 2010, "Bank Lending during the Financial Crisis of 2008,” Journal of Financial Economics 97, 319-338.

Jayaratne, J. and P. Strahan, 1997, “The Benefits of Bank Branch Deregulation,” New York Federal Reserve Economic Policy Review: December 1997.

Khwaja A., and A. Mian, 2005, “Tracing the Impact of Bank Liquidity Shocks: Evidence from an Emerging Market,” American Economic Review, 1413-1442. 
Liberti, J., and A. Mian, 2009, "Estimating the Effect of Hierarchies on Information Use," Review of Financial Studies 22, 4057-4090.

Mayer, C. and K. Pence, 2008, “Subprime Mortgages: What, Where, and to Whom?” Working Paper.

Mester, L., L. Nakamura and M. Renault, 2001, “Checking Accounts and Bank Monitoring,” Working paper.

Mian, A., K. Rao and A. Sufi, 2013, "Household Balancesheets, Consumption, and the Economic Slum,” The Quarterly Journal of Economics: 128(4): 1687-1726.

Peek, J., and E. Rosengren, 1997, "The International Transmission of Financial Shocks: The Case of Japan,” American Economic Review 87, 495-505.

Peek, J., and E. Rosengren, 2000, "Collateral Damage: Effects of the Japanese Bank Crisis on Real Activity in the United States," American Economic Review 90, 30-45.

Petersen, M., and R. Rajan, 2002, "Does Distance Still Matter? The Information Revolution in Small Business Lending,” Journal of Finance 57, 2533-2570.

Rice, T. and P. Strahan, 2010, “Does Credit Competition Affect Small-Firm Finance?” Journal of Finance 65: 861-889.

Schnabl, P., 2012, "The International Transmission of Bank Liquidity Shocks: Evidence from an Emerging Market,” Journal of Finance 67, 897-932.

Stein. J. 2002, "Information Production and Capital Allocation: Decentralized vs Hierarchical Firms," Journal of Finance 57: 1891-1921.

Strahan, P., 2003, "The Real Effects of US Banking Deregulation,” Federal Reserve Bank of St. Louis Review. 


\section{Figure 1}

\section{Concentration of Bank Assets and Small Business Lending}

This figure shows the share of total bank assets (left panel) and of total small business lending (right panel) owned by the top 5 and top 6-20 banks. Institutions are ranked by their presence and activities in each sector individually; the top 5 banks in small business lending are not necessarily the top 5 banks by assets.
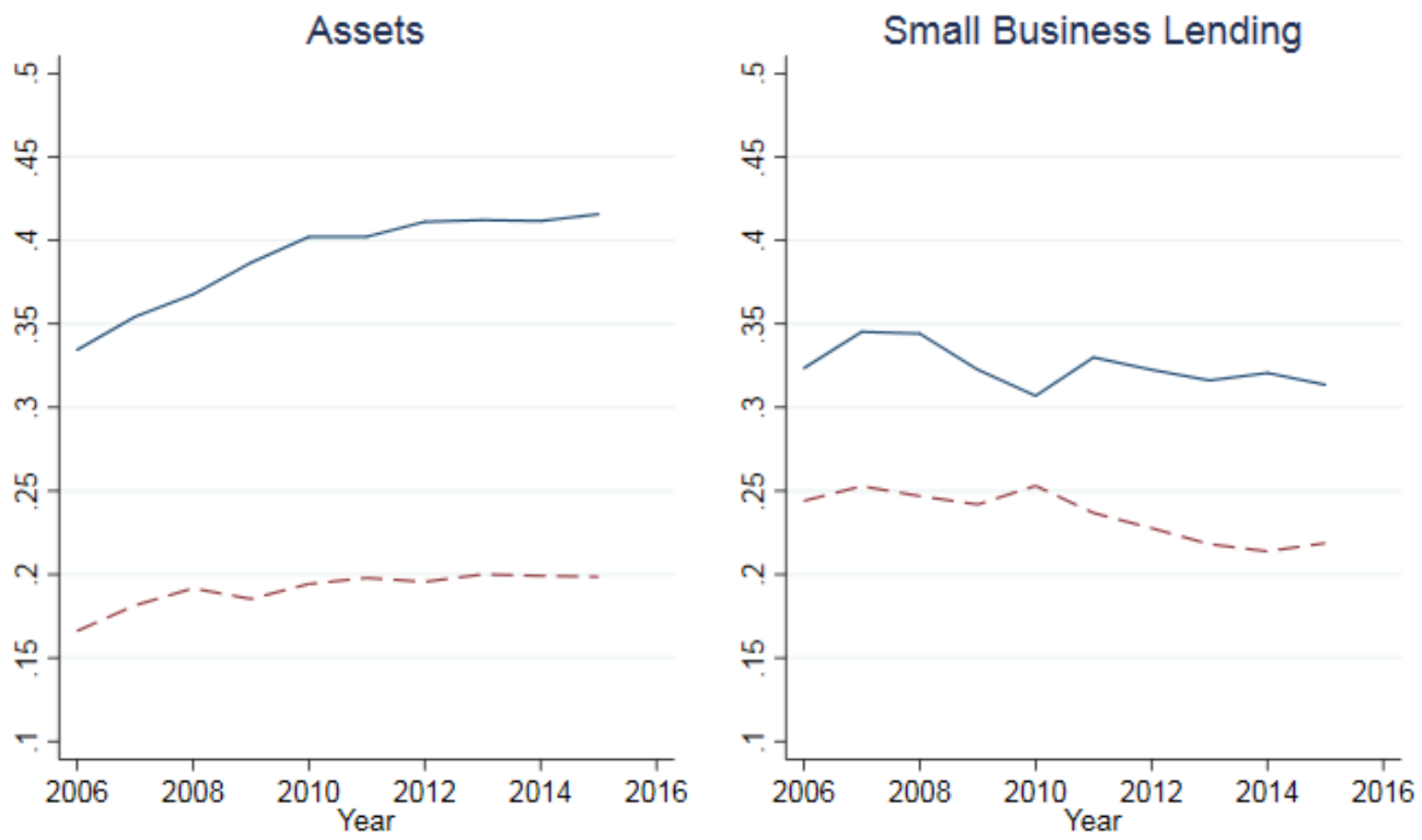

$$
\begin{array}{ll}
- & \text { Top } 5 \text { Share } \\
----- & \text { Top 6-20 Share }
\end{array}
$$




\section{Figure 2}

The Effect of the Real Estate Shock on Healthy and Exposed Banks

This figure shows the effect of the real estate shock on various characteristics of healthy and exposed banks over time.
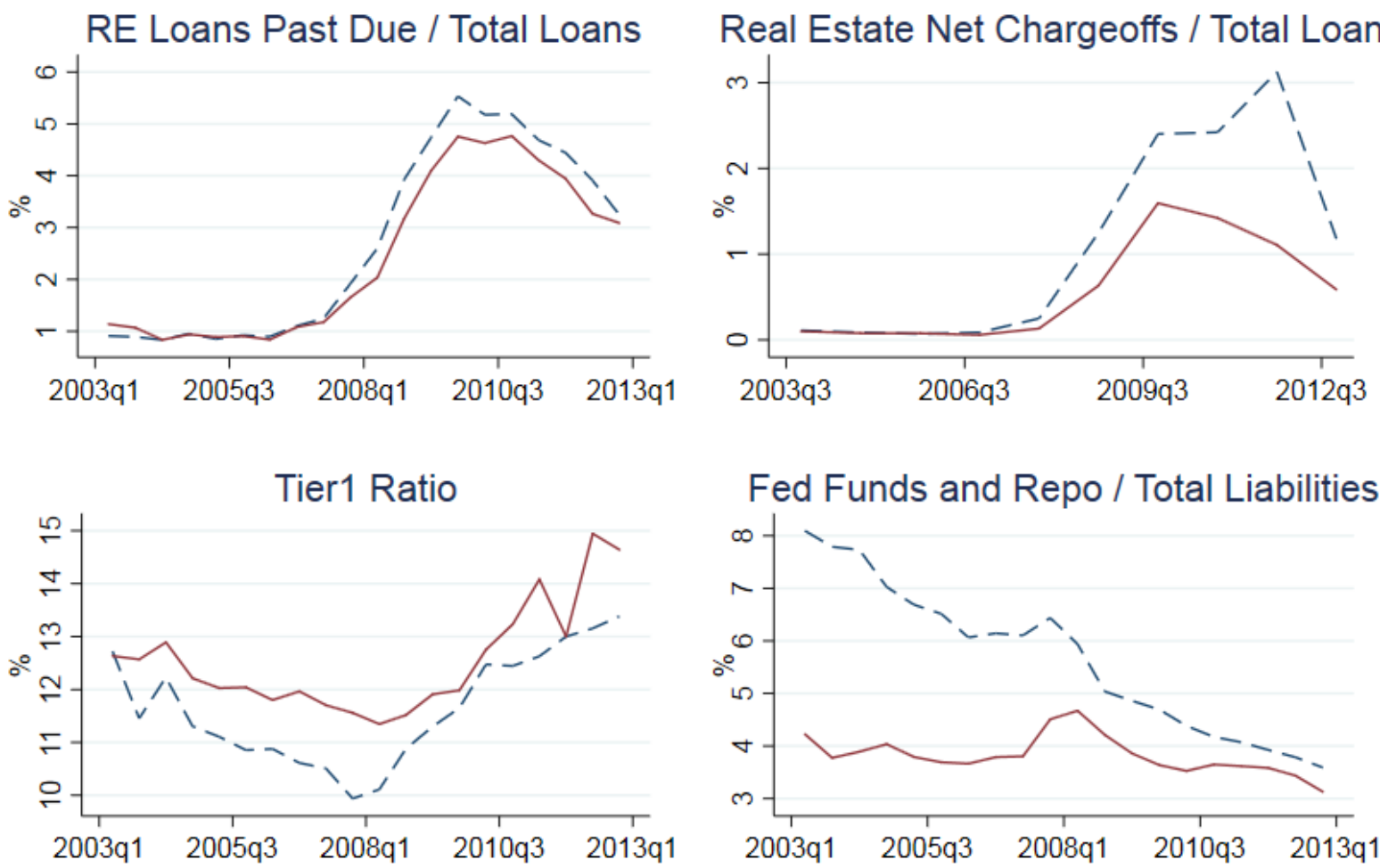

$$
----- \text { Exposed }
$$




\section{Figure 2}

\section{Loan Volume, 1996-2015}

This figure shows the evolution of lending to small firms by loan size. Loan volume is indexed to 2006 levels. The figure reports an equal weighted average across counties that did not experience a drop in real estate prices, focusing on the difference between exposed and healthy dispersed banks.
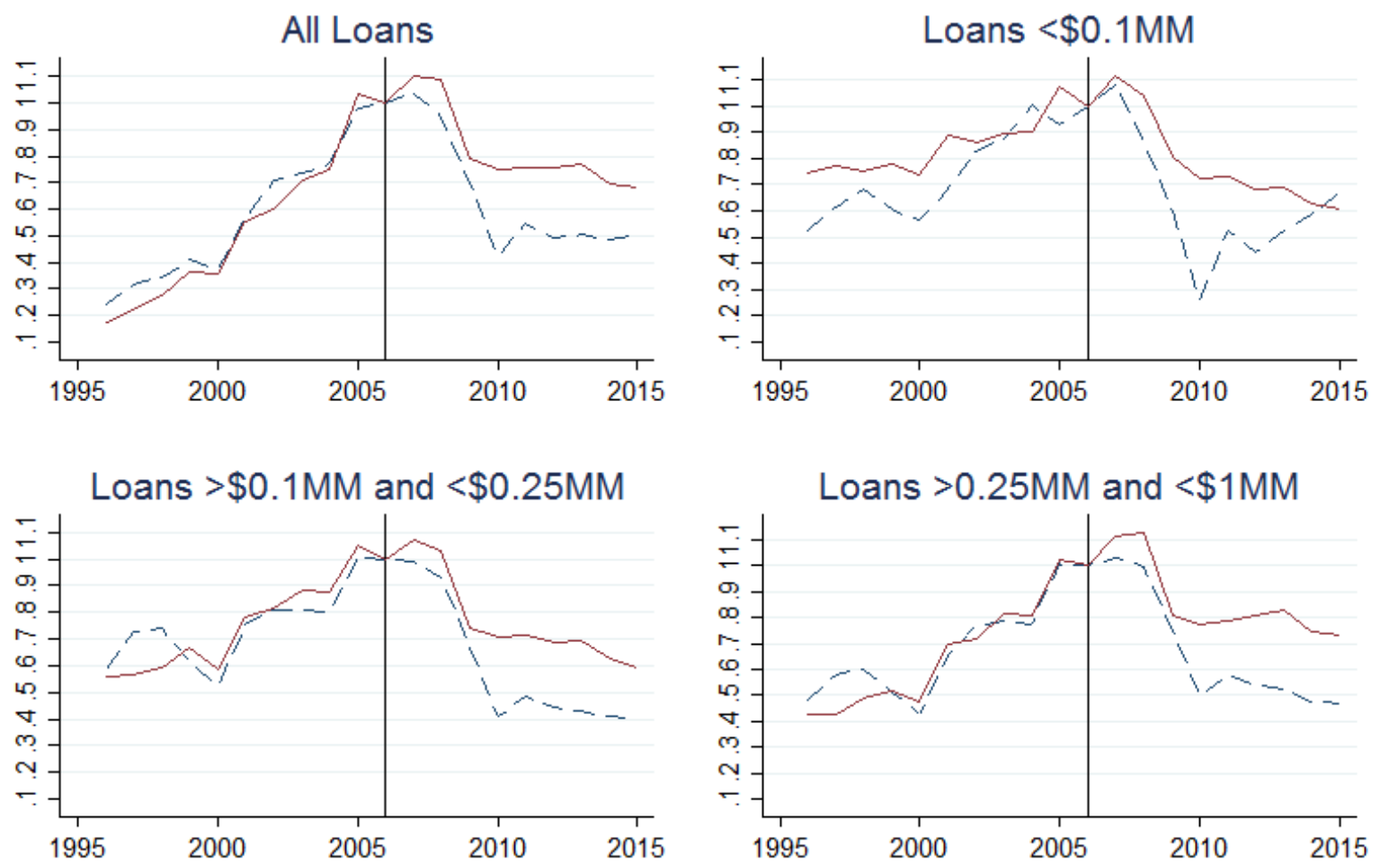

$$
\text { ---- Exposed - Healthy }
$$

Test of trends in lending by exposed and healthy banks prior to 2006 (top left panel):

$L_{i l t}=\alpha+\beta$ Healthy bank $+\gamma t+\zeta t$ x Healthy bank $\mathrm{b}_{\mathrm{i}}+\delta_{l}+\varepsilon_{i l}$

\begin{tabular}{ll}
\hline Healthy bank & \\
& -0.296 \\
Linear time trend $(\mathrm{t})$ & $(0.207)$ \\
& $0.073^{* * *}$ \\
& $(0.022)$ \\
Interaction $\left(t \times G_{t}\right)$ & 0.027 \\
& $(0.022)$ \\
& \\
Fixed effect: County $\left(\delta_{l}\right)$ & Yes \\
Observations & 37559 \\
$R^{2}$ & 0.156 \\
\hline
\end{tabular}




\section{Table 1}

\section{Bank Characteristics}

This table compares banks exposed to the real estate shock and banks that were unaffected by the real estate shock as of June 30, 2006. The first 3 columns correspond to the full sample. The fourth and fifth columns exclude banks in the top 10 by size. There are no healthy banks in the top 10 banks by size. ${ }^{* * *}$, **, and * indicate statistical significance at the $1 \%, 5 \%$, and $10 \%$ level, respectively.

\begin{tabular}{|c|c|c|c|c|c|c|c|}
\hline & $\begin{array}{r}\text { Exposed } \\
\text { banks } \\
(\text { Obs. }=79) \\
\end{array}$ & $\begin{array}{r}\text { Healthy } \\
\text { banks } \\
\text { (Obs. =195) } \\
\end{array}$ & Diff. & & $\begin{array}{r}\text { Exposed excluding } \\
\text { top10 } \\
(\text { Obs. }=69) \\
\end{array}$ & Diff. & \\
\hline Assets (\$billion) & 100.77 & 3.85 & 96.92 & ${ }^{* * * *}$ & 19.420 & 15.567 & *** \\
\hline Number of branches & 458.23 & 67.52 & 390.71 & ${ }^{* * *}$ & 183.61 & 116.08 & *** \\
\hline Number of counties & 64.77 & 16.01 & 48.77 & $* * *$ & 34.855 & 18.850 & *** \\
\hline Deposits/Total assets & 0.673 & 0.780 & -0.107 & ${ }^{* * * *}$ & 0.714 & -0.076 & $* * *$ \\
\hline Loans/Total assets & 0.647 & 0.682 & -0.034 & $* *$ & 0.661 & -0.020 & \\
\hline Real estate loans/Loans & 0.714 & 0.747 & -0.032 & & 0.733 & -0.013 & \\
\hline Small Biz Loans / Loans & 0.079 & 0.082 & -0.003 & & 0.085 & 0.003 & \\
\hline C\&I loan /Loans & 0.181 & 0.150 & 0.031 & ** & 0.178 & 0.028 & $* *$ \\
\hline Past due/Loans & 0.015 & 0.013 & 0.002 & & 0.014 & 0.001 & \\
\hline Net charge-offs/Loans & 0.001 & 0.001 & 0.000 & * & 0.001 & 0.000 & \\
\hline MBS/Assets & 0.098 & 0.083 & 0.016 & & 0.098 & 0.015 & \\
\hline $\begin{array}{l}\text { Contingent claims/Total } \\
\text { assets }\end{array}$ & 0.001 & 0.000 & 0.001 & & 0.001 & 0.001 & \\
\hline Tier 1 capital ratio & 0.107 & 0.119 & -0.012 & $* *$ & 0.110 & -0.008 & \\
\hline $\begin{array}{l}\text { Number of banks acquired } \\
2006-2009\end{array}$ & 16 & 27 & 11 & & & & \\
\hline $\begin{array}{l}\text { Total bank assets acquired } \\
\text { 2006-2009 (in \$billions) }\end{array}$ & $\$ 196$ & $\$ 254$ & $\$ 60$ & & & & \\
\hline
\end{tabular}


Table 2

Change in Lending and Deposits: Exposed Banks vs. Healthy Banks

This table compares the evolution of deposits and loans from 2006 to 2008 for exposed and healthy banks in our sample. The analysis is constrained to counties that did not experience a collapse in real estate prices. Each observation corresponds to a bank-county pair. ***, **, and * indicate statistical significance at the $1 \%$, $5 \%$, and $10 \%$ level, respectively.

\begin{tabular}{|c|c|c|c|c|c|c|}
\hline \multirow[b]{3}{*}{ Variable: } & \multicolumn{6}{|c|}{ Counties unaffected by the direct real estate shock } \\
\hline & \multicolumn{2}{|c|}{ Exposed banks } & \multicolumn{2}{|c|}{ Healthy banks } & \multirow[b]{2}{*}{ Diff. } & \\
\hline & Mean & Obs. & Mean & Obs. & & \\
\hline Number of loans to small enterprise, $2006(1,000 s)$ & 0.215 & 2,027 & 0.141 & 1,587 & 0.074 & ${ }^{* * * *}$ \\
\hline Amount of loans to small enterprise, 2006 (\$million) & 23.461 & 2,027 & 18.757 & 1,587 & 4.704 & ** \\
\hline \multicolumn{7}{|l|}{ Percent change between 2006 and 2008: } \\
\hline Number of small business loans & -0.152 & 2,027 & 0.016 & 1,587 & -0.168 & $* * *$ \\
\hline Number of loans that are $<100 \mathrm{~K}$ & -0.198 & 2,027 & -0.008 & 1,587 & -0.190 & *** \\
\hline Number of loans that are $>100 \mathrm{~K}$ and $<250 \mathrm{~K}$ & -0.111 & 2,027 & 0.027 & 1,587 & -0.139 & $* * *$ \\
\hline Number of loans that are $>250 \mathrm{~K}$ and $<1 \mathrm{M}$ & -0.052 & 2,027 & 0.111 & 1,587 & -0.163 & $* * *$ \\
\hline Number of loans to firms with $<\$ 1 \mathrm{M}$ revenue & -0.232 & 2,027 & -0.101 & 1,587 & -0.131 & **** \\
\hline Number of loans to firms with $>\$ 1 \mathrm{M}$ revenue & -0.104 & 2,027 & 0.219 & 1,587 & -0.323 & *** \\
\hline Amount of small business loans & -0.090 & 2,027 & 0.077 & 1,587 & -0.167 & **** \\
\hline Amount of loans that are $<100 \mathrm{~K}$ & -0.146 & 2,027 & 0.006 & 1,587 & -0.152 & $* * *$ \\
\hline Amount of loans that are $>100 \mathrm{~K}$ and $<250 \mathrm{~K}$ & -0.074 & 2,027 & 0.026 & 1,587 & -0.100 & *** \\
\hline Amount of loans that are $>250 \mathrm{~K}$ and $<1 \mathrm{M}$ & -0.038 & 2,027 & 0.105 & 1,587 & -0.143 & *** \\
\hline Amount of loans to firms with $<\$ 1 \mathrm{M}$ revenue & -0.136 & 2,027 & -0.040 & 1,587 & -0.096 & *** \\
\hline Amount of loans to firms with $>\$ 1 \mathrm{M}$ revenue & -0.040 & 2,027 & 0.181 & 1,587 & -0.221 & *** \\
\hline Number of branches & 0.019 & 1,951 & 0.065 & 1,557 & -0.046 & *** \\
\hline Deposits/Assets & 0.002 & 1,951 & 0.008 & 1,557 & -0.006 & $* * *$ \\
\hline Deposits & -0.095 & 1,951 & 0.101 & 1,557 & -0.196 & $* * *$ \\
\hline
\end{tabular}


Table 3

Change in Lending, 2008 vs. 2006

The analysis is constrained to counties that did not experience a collapse in real estate prices. In Panel A, the variable of interest is Healthy bank, equal to 1 if a bank was not exposed to the collapse in real estate prices across the counties in which it operates. Specifications (1)-(5) correspond to the main result (with increasing number of controls). In Panel $\mathrm{B}$, we interact the Healthy bank indicator with an indicator for whether the bank engaged in an acquisition of another institution in that county during the 2006-2008 period, Engaged in $M \& A_{i l}$. Standard errors (reported in brackets) are clustered at the bank level. ${ }^{* * *},{ }^{* *}$, and * indicate statistical significance at the $1 \%, 5 \%$, and $10 \%$ level, respectively

Panel A: Change in Lending

\begin{tabular}{|c|c|c|c|c|c|}
\hline \multirow[t]{2}{*}{ Dependent variable: } & \multicolumn{5}{|c|}{$\% \Delta$ Loan amount } \\
\hline & $(1)$ & $(2)$ & (3) & (4) & (5) \\
\hline Healthy bank & $\begin{array}{l}0.156^{* * *} \\
(0.051)\end{array}$ & $\begin{array}{l}0.162^{* * *} \\
(0.046)\end{array}$ & $\begin{array}{l}0.218 * * \\
(0.087)\end{array}$ & $\begin{array}{l}0.237 * * * \\
(0.079)\end{array}$ & $\begin{array}{l}0.252 * * * \\
(0.076)\end{array}$ \\
\hline Log(SBL loans in county), 2006 & & $\begin{array}{l}-0.091 * * * \\
(0.021)\end{array}$ & $\begin{array}{l}-0.092^{* * *} \\
(0.021)\end{array}$ & $\begin{array}{l}-0.100^{* * *} \\
(0.019)\end{array}$ & $\begin{array}{l}-0.103^{* * *} \\
(0.018)\end{array}$ \\
\hline Log(Assets), 2006 & -- & -- & $\begin{array}{l}0.016 \\
(0.015)\end{array}$ & $\begin{array}{l}0.061 * * * \\
(0.023)\end{array}$ & $\begin{array}{l}0.081 * * * \\
(0.024)\end{array}$ \\
\hline Deposits/Assets, 2006 & -- & -- & -- & $\begin{array}{l}0.749 * * * \\
(0.263)\end{array}$ & $\begin{array}{l}0.926 * * * \\
(0.273)\end{array}$ \\
\hline Insured deposits/Deposits, 2006 & -- & -- & -- & $\begin{array}{l}-0.234 \\
(0.184)\end{array}$ & $\begin{array}{l}-0.458^{* *} \\
(0.202)\end{array}$ \\
\hline Loans/Assets, 2006 & -- & -- & -- & $\begin{array}{l}0.099 \\
(0.254)\end{array}$ & $\begin{array}{l}0.227 \\
(0.246)\end{array}$ \\
\hline Real estate loans/Total loans, 2006 & -- & -- & -- & $\begin{array}{l}0.126 \\
(0.180)\end{array}$ & $\begin{array}{l}0.278 \\
(0.208)\end{array}$ \\
\hline Net Charge-offs/Total loans, 2006 & -- & -- & -- & -- & $\begin{array}{l}17.385 \\
(16.865)\end{array}$ \\
\hline Past due loans/Total loans, 2006 & -- & -- & -- & -- & $\begin{array}{l}-0.083 \\
(2.952)\end{array}$ \\
\hline Tier 1 ratio, 2006 & -- & -- & -- & -- & $\begin{array}{l}1.816^{* *} \\
(0.908)\end{array}$ \\
\hline ABS/Assets, 2006 & -- & -- & -- & -- & $\begin{array}{l}2.586 \\
(2.029)\end{array}$ \\
\hline Fixed effect: County & -- & Yes & Yes & Yes & Yes \\
\hline Observations & 3499 & 3499 & 3499 & 3207 & 3207 \\
\hline$R$-sq. & 0.062 & 0.267 & 0.270 & 0.300 & 0.310 \\
\hline
\end{tabular}

Panel B: The role of M\&A

\begin{tabular}{llllll}
\hline Dependent variable: & \multicolumn{5}{c}{$\% \Delta$ Loan amount } \\
\cline { 2 - 6 } & $(1)$ & $(2)$ & $(3)$ & $(4)$ & $(5)$ \\
Healthy bank & $0.105^{* * *}$ & $0.105^{* * *}$ & $0.118^{*}$ & $0.145^{* *}$ & $0.160^{* * *}$ \\
& $(0.038)$ & $(0.038)$ & $(0.065)$ & $(0.057)$ & $(0.055)$ \\
Healthy bank x Engaged in M\&A & $0.345^{* *}$ & $0.368^{* * *}$ & $0.367^{* * *}$ & $0.247^{*}$ & $0.229^{*}$ \\
& $(0.152)$ & $(0.136)$ & $(0.136)$ & $(0.130)$ & $(0.130)$ \\
Engaged in M\&A & 0.152 & $0.285^{* * *}$ & $0.285^{* * *}$ & $0.386^{* * *}$ & $0.419^{* * *}$ \\
& $(0.108)$ & $(0.108)$ & $(0.109)$ & $(0.109)$ & $(0.113)$ \\
Bank Controls & & & & & \\
Fixed effect: County & Yes & Yes & Yes & Yes & Yes \\
Observations & -- & Yes & Yes & Yes & Yes \\
$R$-sq. & 3,499 & 3,499 & 3,499 & 3,207 & 3,207 \\
F-stat & 0.084 & 0.280 & 0.280 & 0.311 & 0.318 \\
& $16.70^{* * *}$ & $21.19^{* * *}$ & $24.78^{* * *}$ & $26.16^{* * *}$ & $26.01^{* * *}$ \\
\hline
\end{tabular}


Table 4

Change in Lending, 2008 vs. 2006: Robustness

This table repeats the analysis in Table 3, specification (5). In specification (1), we limit the analysis only to counties in the top three quartiles of the percent of highpriced HMDA mortgages originated from 2004-2006. The sample used in specification (2) excludes the ten biggest banks. In specification (3), we discard observations where a given bank had entered after 2002 (i.e., new or non-traditional markets). In specification (4), we change the definition of the variables; specifically, "large" banks are defined as those in the top quartile of the distribution of the number of counties each bank operates in and "exposed" as the top quartile of the distribution of the number of weak counties each bank operates in. In specification (5), we change our control group from healthy geographically dispersed banks to local banks. Because the analysis is constrained to counties that did not experienced contraction in real estate prices, local banks were also not exposed to the real estate shock. In specification (6), we use the continuous measure of exposure; Healthy bank is based on the quartiles of this measure. All specifications include county fixed effects and bank controls listed in Table 3, Specification (5). Standard errors (reported in brackets) are clustered at the bank level. ***, **, and * indicate statistical significance at the $1 \%, 5 \%$, and $10 \%$ level, respectively.

\begin{tabular}{|c|c|c|c|c|c|c|}
\hline Dependent variable: & $\begin{array}{l}\text { Uses Measure } \\
\text { of Subprime } \\
\text { (1) }\end{array}$ & $\begin{array}{l}\text { Excludes Top } 10 \\
\text { Banks } \\
(2) \\
\end{array}$ & $\begin{array}{l}\text { Excludes } \\
\text { counties } \\
\text { entered post } \\
2002 \\
(3) \\
\end{array}$ & $\begin{array}{l}\text { Alternative } \\
\text { Definitions of } \\
\text { Dispersed, } \\
\text { Healthy } \\
\text { (4) } \\
\end{array}$ & $\begin{array}{l}\text { Control group } \\
\text { is local healthy } \\
\text { banks } \\
\text { (5) }\end{array}$ & $\begin{array}{l}\text { Continuous } \\
\text { Measure } \\
\text { (6) } \\
\end{array}$ \\
\hline Healthy bank & $\begin{array}{l}0.301 * * * \\
(0.086)\end{array}$ & $\begin{array}{l}0.248 * * * \\
(0.089)\end{array}$ & $\begin{array}{l}0.154^{* *} \\
(0.067)\end{array}$ & $\begin{array}{l}0.161 * * * \\
(0.060)\end{array}$ & $\begin{array}{l}0.174 * \\
(0.103)\end{array}$ & $\begin{array}{l}-- \\
--\end{array}$ \\
\hline Continuous Measure of Exposure $i$ & $\begin{array}{l}-- \\
--\end{array}$ & $\begin{array}{l}-- \\
--\end{array}$ & $\begin{array}{l}-- \\
--\end{array}$ & $\begin{array}{l}-- \\
--\end{array}$ & $\begin{array}{l}-- \\
--\end{array}$ & $\begin{array}{l}2.755^{*} \\
(1.444)\end{array}$ \\
\hline $\begin{array}{l}\text { Bank Controls } \\
\text { Fixed effect: County } \\
\text { Observations } \\
R \text {-sq. }\end{array}$ & $\begin{array}{l}\text { Yes } \\
\text { Yes } \\
2,355 \\
0.330 \\
\end{array}$ & $\begin{array}{l}\text { Yes } \\
\text { Yes } \\
2,099 \\
0.403 \\
\end{array}$ & $\begin{array}{l}\text { Yes } \\
\text { Yes } \\
2,188 \\
0.371 \\
\end{array}$ & $\begin{array}{l}\text { Yes } \\
\text { Yes } \\
3,285 \\
0.286 \\
\end{array}$ & $\begin{array}{l}\text { Yes } \\
\text { Yes } \\
2,426 \\
0.335 \\
\end{array}$ & $\begin{array}{l}\text { Yes } \\
\text { Yes } \\
3,207 \\
0.295 \\
\end{array}$ \\
\hline
\end{tabular}


Table 5

\section{Extensive Margin}

In Panel A, the dependent variable is an indicator equal to 1 if a bank that had branches in the country as of June 2006 but no longer has branches in that county as of June 2008, and 0 otherwise. Specification (3) excludes observations corresponding to exit due to bank failure and M\&A activity. In Panel B, the dependent variable is equal to 1 if the bank entered the county between June 2006 and June 2008, and a probit is estimated. The last line of each Panel shows the marginal effect of Healthy bank . Standard errors (reported in brackets) are clustered at the bank level. ***, **, and * indicate statistical significance at the $1 \%, 5 \%$, and $10 \%$ level, respectively.

\begin{tabular}{|c|c|c|c|}
\hline & $\begin{array}{l}\text { OLS } \\
(1)\end{array}$ & $\begin{array}{l}\text { Probit } \\
\text { (2) }\end{array}$ & $\begin{array}{l}\text { Probit } \\
\text { (3) }\end{array}$ \\
\hline Healthy bank & $\begin{array}{l}-0.208^{* * *} \\
(0.073)\end{array}$ & $\begin{array}{l}-0.993 * * * \\
(0.295)\end{array}$ & $\begin{array}{l}-0.669 * * \\
(0.307)\end{array}$ \\
\hline Change in real estate prices 2002Q2-2006Q2 & -- & $\begin{array}{l}0.063 \\
(1.174)\end{array}$ & $\begin{array}{l}-0.695 \\
(1.236)\end{array}$ \\
\hline Change in real estate prices 2006Q2-2007Q4 & -- & $\begin{array}{l}-0.204 \\
(0.406)\end{array}$ & $\begin{array}{l}-0.405 \\
(0.408)\end{array}$ \\
\hline Debt to Income Ratio, as of 2006 & -- & $\begin{array}{l}-0.195 \\
(0.132)\end{array}$ & $\begin{array}{l}-0.221 \\
(0.184)\end{array}$ \\
\hline Number of households (million) & -- & $\begin{array}{l}-0.771 \\
(3.340)\end{array}$ & $\begin{array}{l}-5.197 \\
(3.968)\end{array}$ \\
\hline Total population (million) & -- & $\begin{array}{l}0.302 \\
(1.234)\end{array}$ & $\begin{array}{l}2.000 \\
(1.436)\end{array}$ \\
\hline Median household income (\$ thousand) & -- & $\begin{array}{l}3.129 \\
(9.456)\end{array}$ & $\begin{array}{l}6.247 \\
(10.718)\end{array}$ \\
\hline Number of houses per square mile & -- & $\begin{array}{l}81.830 \\
(68.265)\end{array}$ & $\begin{array}{l}75.892 \\
(86.637)\end{array}$ \\
\hline Fraction of population below the poverty line & -- & $\begin{array}{l}0.296 \\
(2.062)\end{array}$ & $\begin{array}{l}-2.422 \\
(2.591)\end{array}$ \\
\hline Fraction of labor force unemployed & -- & $\begin{array}{l}-0.534 \\
(4.385)\end{array}$ & $\begin{array}{l}4.799 \\
(4.894)\end{array}$ \\
\hline Fraction of labor employed in real estate & -- & $\begin{array}{l}0.821 \\
(2.673)\end{array}$ & $\begin{array}{l}-2.109 \\
(3.975)\end{array}$ \\
\hline Fraction of labor employed in finance & -- & $\begin{array}{l}3.809 * \\
(2.030)\end{array}$ & $\begin{array}{l}2.268 \\
(2.453)\end{array}$ \\
\hline Fraction of labor employed in construction & -- & $\begin{array}{l}-18.285^{*} \\
(9.803)\end{array}$ & $\begin{array}{l}-11.360 \\
(11.913)\end{array}$ \\
\hline Bank Controls & Yes & Yes & Yes \\
\hline Fixed effect: County & Yes & -- & -- \\
\hline Observations & 3,897 & 3,828 & 3,494 \\
\hline$R$-sq. & 0.290 & 0.165 & 0.218 \\
\hline Marginal Effect of Healthy Bank & & $\begin{array}{l}-0.108^{* * *} \\
(0.042)\end{array}$ & $\begin{array}{l}-0.038^{*} \\
(0.021)\end{array}$ \\
\hline
\end{tabular}




\begin{tabular}{|c|c|c|c|c|}
\hline & & & & \\
\hline & (1) & (2) & (3) & (4) \\
\hline Healthy bank & $\begin{array}{l}0.513 * * * \\
(0.120)\end{array}$ & $\begin{array}{l}1.077 * * * \\
(0.302)\end{array}$ & $\begin{array}{l}0.237 \\
(0.191)\end{array}$ & $\begin{array}{l}0.422 \\
(0.347)\end{array}$ \\
\hline - Log (Number of new banks, 1996-2005) & -- & $\begin{array}{l}-0.475^{* * *} \\
(0.137)\end{array}$ & -- & -- \\
\hline Healthy bank x -Log (Number of new banks) & -- & $\begin{array}{l}0.250 * * \\
(0.120)\end{array}$ & -- & -- \\
\hline Deposits HHI (2006) & -- & -- & $\begin{array}{l}-0.138^{*} \\
(0.076)\end{array}$ & -- \\
\hline Healthy bank x Deposits HHI & -- & -- & $\begin{array}{l}0.135 * \\
(0.078)\end{array}$ & -- \\
\hline Rice and Strahan (2010) index & -- & -- & -- & $\begin{array}{l}-0.248^{* *} \\
(0.110)\end{array}$ \\
\hline Healthy bank x Rice-Strahan index & -- & -- & -- & $\begin{array}{l}0.194^{*} \\
(0.139)\end{array}$ \\
\hline Bank Controls & Yes & Yes & Yes & Yes \\
\hline County level controls (as in Panel A) & Yes & Yes & Yes & Yes \\
\hline Observations & 6,484 & 6,484 & 6,484 & 1,421 \\
\hline$R$-sq. & 0.082 & 0.091 & 0.086 & 0.187 \\
\hline Marginal Effect of Healthy Bank & $\begin{array}{l}0.029 * * * \\
(0.007)\end{array}$ & $\begin{array}{l}0.033 * * * \\
(0.007)\end{array}$ & $\begin{array}{l}0.032 * * * \\
(0.007)\end{array}$ & $\begin{array}{l}0.030 * * \\
(0.012)\end{array}$ \\
\hline
\end{tabular}




\section{Table 6}

\section{Deposits and Branches}

This table examines whether healthy banks are more likely to expand their deposit and branch growth. Specifications (1)-(2) focus on the change in the log of deposits and in number of branches in counties where the bank already has branches, respectively. In specification (3), the dependent variable is equal to 1 if the number of branches increased, 0 if it stayed the same, and - 1 if it decreased, and an ordered probit is estimated. In specification (4), the dependent variable is deposits per branch. Specification (5) includes observations corresponding to both exit from and entry into a county and the dependent variable is the change in the market share from 2006 to 2008. In Panel B, we interact the Healthy $b_{a n k}$ indicator with Engaged in M\&Ail, an indicator for whether the bank engaged in an acquisition of another institution in that county during the 2006-2008 period. Standard errors (reported in brackets) are clustered at the bank level. ***, $* *$, and * indicate statistical significance at the $1 \%, 5 \%$, and $10 \%$ level, respectively.

\section{Panel A: Change in Deposits}

\begin{tabular}{|c|c|c|c|c|c|}
\hline Dependent variable: & $\begin{array}{l}\% \Delta \text { Deposits } \\
\text { (1) }\end{array}$ & $\begin{array}{l}\% \Delta \text { Branches } \\
\text { (2) }\end{array}$ & $\begin{array}{c}\Delta \text { Branches } \\
\text { (Ordinal) } \\
\text { (3) }\end{array}$ & $\begin{array}{l}\% \Delta \text { Deposits (per } \\
\text { branch) } \\
\text { (4) }\end{array}$ & $\begin{array}{l}\Delta \text { Market share of } \\
\text { deposits } \\
\text { (5) }\end{array}$ \\
\hline Healthy bank & $\begin{array}{l}0.076^{*} \\
(0.042)\end{array}$ & $\begin{array}{l}0.059 * * \\
(0.027)\end{array}$ & $\begin{array}{l}0.223 * \\
(0.122)\end{array}$ & $\begin{array}{l}-0.061 \\
(0.082)\end{array}$ & $\begin{array}{l}0.025^{* * *} \\
(0.009)\end{array}$ \\
\hline Log(Assets), 2006 & $\begin{array}{l}0.033^{* *} \\
(0.014)\end{array}$ & $\begin{array}{l}0.001 \\
(0.007)\end{array}$ & $\begin{array}{l}-0.052 \\
(0.039)\end{array}$ & $\begin{array}{l}0.060 * * \\
(0.027)\end{array}$ & $\begin{array}{l}0.004^{* *} \\
(0.002)\end{array}$ \\
\hline Deposits/Assets, 2006 & $\begin{array}{l}0.082 \\
(0.213)\end{array}$ & $\begin{array}{l}-0.098 \\
(0.105)\end{array}$ & $\begin{array}{l}-0.689 \\
(0.590)\end{array}$ & $\begin{array}{l}0.551 \\
(0.438)\end{array}$ & $\begin{array}{l}-0.016 \\
(0.021)\end{array}$ \\
\hline $\begin{array}{l}\text { Insured } \\
\text { deposits/Deposits, } 2006\end{array}$ & $\begin{array}{l}-0.127 \\
(0.149)\end{array}$ & $\begin{array}{l}-0.043 \\
(0.074)\end{array}$ & $\begin{array}{l}-0.838^{* *} \\
(0.379)\end{array}$ & $\begin{array}{l}-0.300 \\
(0.261)\end{array}$ & $\begin{array}{l}-0.003 \\
(0.014)\end{array}$ \\
\hline Loans/Assets, 2006 & $\begin{array}{l}0.380 * * \\
(0.166)\end{array}$ & $\begin{array}{l}0.152 * \\
(0.079)\end{array}$ & $\begin{array}{l}0.684 * \\
(0.405)\end{array}$ & $\begin{array}{l}0.182 \\
(0.364)\end{array}$ & $\begin{array}{l}0.016 \\
(0.016)\end{array}$ \\
\hline $\begin{array}{l}\text { Real estate loans/Total } \\
\text { loans, } 2006\end{array}$ & $\begin{array}{l}-0.098 \\
(0.134)\end{array}$ & $\begin{array}{l}-0.017 \\
(0.046)\end{array}$ & $\begin{array}{l}0.379 \\
(0.258)\end{array}$ & $\begin{array}{l}-0.199 \\
(0.272)\end{array}$ & $\begin{array}{l}-0.001 \\
(0.013)\end{array}$ \\
\hline $\begin{array}{l}\text { Net Charge-offs/Total } \\
\text { loans, } 2006\end{array}$ & $\begin{array}{l}-3.160 \\
(17.950)\end{array}$ & $\begin{array}{l}6.499 \\
(6.132)\end{array}$ & $\begin{array}{l}59.383 * \\
(30.892)\end{array}$ & $\begin{array}{l}-9.182 \\
(33.122)\end{array}$ & $\begin{array}{l}-0.824 \\
(1.795)\end{array}$ \\
\hline $\begin{array}{l}\text { Past due loans/Total } \\
\text { loans, } 2006\end{array}$ & $\begin{array}{l}-3.524 * \\
(1.994)\end{array}$ & $\begin{array}{l}-0.407 \\
(0.953)\end{array}$ & $\begin{array}{l}2.907 \\
(4.484)\end{array}$ & $\begin{array}{l}-6.155^{*} \\
(3.660)\end{array}$ & $\begin{array}{l}0.097 \\
(0.229)\end{array}$ \\
\hline Tier 1 ratio, 2006 & $\begin{array}{l}0.687 \\
(0.823)\end{array}$ & $\begin{array}{l}-0.075 \\
(0.262)\end{array}$ & $\begin{array}{l}0.945 \\
(1.402)\end{array}$ & $\begin{array}{l}2.625 \\
(1.746)\end{array}$ & $\begin{array}{l}0.041 \\
(0.051)\end{array}$ \\
\hline ABS/Assets, 2006 & $\begin{array}{l}1.892 \\
(1.534)\end{array}$ & $\begin{array}{l}0.426 \\
(0.358)\end{array}$ & $\begin{array}{l}-0.243 \\
(2.446)\end{array}$ & $\begin{array}{l}4.131 \\
(3.770)\end{array}$ & $\begin{array}{l}0.428^{* *} \\
(0.189)\end{array}$ \\
\hline Log(Deposits), 2006 & $\begin{array}{l}-0.131 * * * \\
(0.013)\end{array}$ & $\begin{array}{l}-0.014 * * * \\
(0.004)\end{array}$ & $\begin{array}{l}-0.010 \\
(0.029)\end{array}$ & $\begin{array}{l}-0.336^{* * *} \\
(0.051)\end{array}$ & -- \\
\hline $\begin{array}{l}\text { Log(Num Branches), } \\
2006\end{array}$ & -- & $\begin{array}{l}-0.003^{* * *} \\
(0.001)\end{array}$ & $\begin{array}{l}-0.025^{* * *} \\
(0.007)\end{array}$ & -- & -- \\
\hline $\begin{array}{l}\text { Fixed effect: County } \\
\text { County controls } \\
\text { Observations } \\
R \text {-sq. }\end{array}$ & $\begin{array}{l}\text { Yes } \\
-- \\
3,208 \\
0.335\end{array}$ & $\begin{array}{l}\text { Yes } \\
-- \\
3,209 \\
0.270\end{array}$ & $\begin{array}{l}-- \\
\text { Yes } \\
3,184 \\
0.058\end{array}$ & $\begin{array}{l}\text { Yes } \\
-- \\
3,208 \\
0.313\end{array}$ & $\begin{array}{l}\text { Yes } \\
-- \\
5,353 \\
0.232\end{array}$ \\
\hline
\end{tabular}


Panel B: The role of M\&A

\begin{tabular}{|c|c|c|c|c|c|}
\hline Dependent variable: & $\begin{array}{l}\% \Delta \text { Deposits } \\
\text { (1) }\end{array}$ & $\begin{array}{l}\% \Delta \text { Branches } \\
\text { (2) }\end{array}$ & $\begin{array}{l}\Delta \text { Branches } \\
\text { (Ordinal) } \\
\text { (3) }\end{array}$ & $\begin{array}{l}\% \Delta \text { Deposits } \\
\text { (per branch) } \\
\text { (4) }\end{array}$ & $\begin{array}{l}\Delta \text { Market share } \\
\text { of deposits } \\
\text { (5) }\end{array}$ \\
\hline Healthy bank & $\begin{array}{l}-0.043 \\
(0.044)\end{array}$ & $\begin{array}{l}-0.009 \\
(0.014)\end{array}$ & $\begin{array}{l}-0.055 \\
(0.072)\end{array}$ & $\begin{array}{l}-0.077 \\
(0.102)\end{array}$ & $\begin{array}{l}0.013 * \\
(0.007)\end{array}$ \\
\hline Healthy bank x Engaged in M\&A & $\begin{array}{l}0.356^{* *} \\
(0.141)\end{array}$ & $\begin{array}{l}0.164 * * * \\
(0.061)\end{array}$ & $\begin{array}{l}0.445^{*} \\
(0.249)\end{array}$ & $\begin{array}{l}0.187 \\
(0.263)\end{array}$ & $\begin{array}{l}0.026^{*} \\
(0.015)\end{array}$ \\
\hline Engaged in M\&A & $\begin{array}{l}0.490^{* * *} \\
(0.124)\end{array}$ & $\begin{array}{l}0.299 * * * \\
(0.067)\end{array}$ & $\begin{array}{l}1.748 * * * \\
(0.298)\end{array}$ & $\begin{array}{l}0.301 \\
(0.276)\end{array}$ & $\begin{array}{l}0.043^{* * *} \\
(0.016)\end{array}$ \\
\hline Fixed effect: County & Yes & Yes & -- & Yes & Yes \\
\hline County controls & -- & -- & Yes & -- & -- \\
\hline Observations & 3207 & 3209 & 3187 & 3207 & 5362 \\
\hline$R$-sq. & 0.418 & 0.426 & .116 & 0.315 & 0.288 \\
\hline
\end{tabular}


Table 7

\section{Long-Term Effects}

This table tests whether the differences in gains in loans and deposits between healthy and exposed banks persist in the long term. In all specifications, the dependent variable is defined as the change from 2006 to 2015. In Panel B, the dependent variables in columns 1 and 3 are the same as in columns 1 and 3 of Panel A. In columns 2 and 4, the dependent variables the pro forma lending and deposit growth, which add the pre-merger loans and deposits of the acquired institutions to the loans and deposits of the acquiring bank. Standard errors (reported in brackets) are clustered at the bank level. ${ }^{* *},{ }^{* *}$, and $*$ indicate statistical significance at the $1 \%, 5 \%$, and $10 \%$ level, respectively.

Panel A: Long-Term Effects

\begin{tabular}{|c|c|c|c|c|}
\hline & $\begin{array}{l}\% \Delta \text { Loans } \\
(1)\end{array}$ & $\begin{array}{l}\Delta \text { Market share } \\
\text { (loans) } \\
(2)\end{array}$ & $\begin{array}{l}\% \Delta \text { Deposits } \\
\text { (3) }\end{array}$ & $\begin{array}{l}\Delta \text { Market share } \\
\text { (deposits) } \\
\text { (4) }\end{array}$ \\
\hline Healthy bank & $\begin{array}{l}0.334 * * * \\
(0.086)\end{array}$ & $\begin{array}{l}0.109 * * * \\
(0.028)\end{array}$ & $\begin{array}{l}0.147 * \\
(0.077)\end{array}$ & $\begin{array}{l}0.040 * * * \\
(0.010)\end{array}$ \\
\hline Log(Assets), 2006 & $\begin{array}{l}0.014 \\
(0.027)\end{array}$ & $\begin{array}{l}0.021^{* * *} \\
(0.006)\end{array}$ & $\begin{array}{l}0.063 * \\
(0.034)\end{array}$ & $\begin{array}{l}0.009 * * * \\
(0.002)\end{array}$ \\
\hline Deposits / Assets, 2006 & $\begin{array}{l}0.809 \\
(0.504)\end{array}$ & $\begin{array}{l}0.052 \\
(0.108)\end{array}$ & $\begin{array}{l}1.466 * * * \\
(0.554)\end{array}$ & $\begin{array}{l}0.057 \\
(0.040)\end{array}$ \\
\hline Insured Deposits / Deposits, 2006 & $\begin{array}{l}-0.640 * * \\
(0.317)\end{array}$ & $\begin{array}{l}-0.013 \\
(0.099)\end{array}$ & $\begin{array}{l}-0.701^{* *} \\
(0.339)\end{array}$ & $\begin{array}{l}-0.044 * \\
(0.026)\end{array}$ \\
\hline Loans / Assets, 2006 & $\begin{array}{l}-1.248^{* * *} \\
(0.351)\end{array}$ & $\begin{array}{l}-0.083 \\
(0.091)\end{array}$ & $\begin{array}{l}-0.792^{* *} \\
(0.384)\end{array}$ & $\begin{array}{l}-0.021 \\
(0.028)\end{array}$ \\
\hline Real Estate Loans / Loans, 2006 & $\begin{array}{l}-0.431^{* *} \\
(0.192)\end{array}$ & $\begin{array}{l}-0.095 \\
(0.075)\end{array}$ & $\begin{array}{l}-0.177 \\
(0.316)\end{array}$ & $\begin{array}{l}-0.018 \\
(0.018)\end{array}$ \\
\hline Net Charge offs / Loans, 2006 & $\begin{array}{l}9.800 \\
(29.346)\end{array}$ & $\begin{array}{l}-9.297 \\
(6.631)\end{array}$ & $\begin{array}{l}69.495^{* *} \\
(27.742)\end{array}$ & $\begin{array}{l}-0.586 \\
(2.500)\end{array}$ \\
\hline Past Due / Loans, 2006 & $\begin{array}{l}-2.457 \\
(5.307)\end{array}$ & $\begin{array}{l}1.281 \\
(0.992)\end{array}$ & $\begin{array}{l}-4.926 \\
(6.095)\end{array}$ & $\begin{array}{l}0.447 \\
(0.377)\end{array}$ \\
\hline Tier 1 ratio, 2006 & $\begin{array}{l}-2.271 \\
(1.873)\end{array}$ & $\begin{array}{l}0.368 \\
(0.314)\end{array}$ & $\begin{array}{l}-0.475 \\
(1.252)\end{array}$ & $\begin{array}{l}0.162 * \\
(0.092)\end{array}$ \\
\hline ABS / Assets, 2006 & $\begin{array}{l}9.786 * * * \\
(2.422)\end{array}$ & $\begin{array}{l}0.777 \\
(0.844)\end{array}$ & $\begin{array}{l}4.229 \\
(4.502)\end{array}$ & $\begin{array}{l}0.742 * * * \\
(0.250)\end{array}$ \\
\hline Log(Deposits in County), 2006 & -- & -- & $\begin{array}{l}-0.255^{* * *} \\
(0.019)\end{array}$ & -- \\
\hline Log(SBL Loans in County), 2006 & $\begin{array}{l}-0.379 * * * \\
(0.029)\end{array}$ & -- & -- & -- \\
\hline Fixed effect: County & Yes & Yes & Yes & Yes \\
\hline Observations & 2,534 & 3,589 & 2,534 & 3,589 \\
\hline$R$-sq. & 0.387 & 0.276 & 0.480 & 0.324 \\
\hline
\end{tabular}


Panel B: The role of M\&A

\begin{tabular}{|c|c|c|c|c|}
\hline & $\begin{array}{l}\% \Delta \text { Loans } \\
(1)\end{array}$ & $\begin{array}{l}\text { \% } \mathrm{\Delta} \text { Loans } \\
\text { (pro-forma) } \\
(2)\end{array}$ & $\begin{array}{l}\% \Delta \text { Deposits } \\
\text { (3) }\end{array}$ & $\begin{array}{l}\% \Delta \text { Deposits } \\
\text { (pro-forma) } \\
(4)\end{array}$ \\
\hline Healthy bank & $\begin{array}{l}0.295 \\
(0.220)\end{array}$ & $\begin{array}{l}0.250 * * \\
(0.098)\end{array}$ & $\begin{array}{l}0.049 \\
(0.114)\end{array}$ & $\begin{array}{l}-0.027 \\
(0.108)\end{array}$ \\
\hline Healthy bank x Engaged in M\&A & $\begin{array}{l}0.470^{*} \\
(0.265)\end{array}$ & & $\begin{array}{l}0.262^{*} \\
(0.154)\end{array}$ & \\
\hline Engaged in $\mathrm{M} \& \mathrm{~A}$ & $\begin{array}{l}0.318 \\
(0.258)\end{array}$ & & $\begin{array}{l}0.323 * * \\
(0.131)\end{array}$ & \\
\hline Bank Controls & Yes & Yes & Yes & Yes \\
\hline Fixed effect: County & Yes & Yes & Yes & Yes \\
\hline Observations & 2,534 & 2262 & 2,545 & 2262 \\
\hline$R$-sq. & 0.401 & 0.426 & 0.494 & 0.481 \\
\hline
\end{tabular}




\section{Table 8}

\section{Aggregate Effect}

This table examines the aggregate effect at the county level. County exposure is measured as the deposit-weighted average, across banks, of the real estate exposure of banks in each county. The main variable of interest, Exposed Countyl, is equal to 1 if the county lies in the top quartile of this distribution. In Panel A, all dependent variables are changes from 2006 to 2008. In Panel B, the dependent variables are changes from 2006 to 2015. All specifications include county controls. The analysis is constrained to counties that did not experience a real estate drop. ***, **, and * indicate statistical significance at the $1 \%$, $5 \%$, and $10 \%$ level, respectively.

\begin{tabular}{|c|c|c|c|c|c|c|c|}
\hline Dependent variable: & $\begin{array}{l}\% \Delta \text { Healthy } \\
\text { loans } \\
(1) \\
\end{array}$ & $\begin{array}{l}\Delta \text { Healthy } \\
\text { market share } \\
\text { (loans) } \\
(2)\end{array}$ & $\begin{array}{l}\text { \% } \Delta \text { Healthy } \\
\text { deposits } \\
(3)\end{array}$ & $\begin{array}{l}\Delta \text { Healthy } \\
\text { market share } \\
\text { (deposits) } \\
\text { (4) }\end{array}$ & $\% \Delta$ Loans & $\% \Delta$ Deposits & $\begin{array}{l}\Delta \text { Deposit } \\
\text { HHI } \\
(7)\end{array}$ \\
\hline Exposed county & $\begin{array}{l}0.10^{*} \\
(0.059)\end{array}$ & $\begin{array}{l}0.068^{* * *} \\
(0.017)\end{array}$ & $\begin{array}{l}0.031^{* * *} \\
(0.012)\end{array}$ & $\begin{array}{l}0.035^{* * *} \\
(0.009)\end{array}$ & $\begin{array}{l}-0.090^{*} \\
(0.054)\end{array}$ & $\begin{array}{l}-0.025^{*} \\
(0.014)\end{array}$ & $\begin{array}{l}-68.787 \\
(47.740)\end{array}$ \\
\hline $\begin{array}{l}\text { County level controls } \\
\text { Observations } \\
R \text {-sq. } \\
\end{array}$ & $\begin{array}{l}\text { Yes } \\
704 \\
0.030 \\
\end{array}$ & $\begin{array}{l}\text { Yes } \\
704 \\
0.054 \\
\end{array}$ & $\begin{array}{l}\text { Yes } \\
704 \\
0.142 \\
\end{array}$ & $\begin{array}{l}\text { Yes } \\
704 \\
0.059 \\
\end{array}$ & $\begin{array}{l}\text { Yes } \\
716 \\
0.027 \\
\end{array}$ & $\begin{array}{l}\text { Yes } \\
716 \\
0.168 \\
\end{array}$ & $\begin{array}{l}\text { Yes } \\
716 \\
0.128 \\
\end{array}$ \\
\hline Panel B: 2006 to 2015 & & & & & & & \\
\hline Dependent variable: & $\begin{array}{l}\% \Delta \text { Healthy } \\
\text { loans } \\
\text { (1) }\end{array}$ & $\begin{array}{l}\Delta \text { Healthy } \\
\text { market share } \\
\text { (loans) } \\
(2)\end{array}$ & $\begin{array}{l}\% \Delta \text { Healthy } \\
\text { deposits } \\
\text { (3) }\end{array}$ & $\begin{array}{l}\Delta \text { Healthy } \\
\text { market share } \\
\text { (deposits) } \\
\text { (4) }\end{array}$ & $\% \Delta$ Loans & $\% \Delta$ Deposits & $\begin{array}{l}\Delta \text { Deposit } \\
\text { HHI } \\
(7)\end{array}$ \\
\hline Exposed county & $\begin{array}{l}0.156^{*} \\
(0.090)\end{array}$ & $\begin{array}{l}0.095 * * * \\
(0.029)\end{array}$ & $\begin{array}{l}0.058^{* * *} \\
(0.019)\end{array}$ & $\begin{array}{l}0.098 * * * \\
(0.017)\end{array}$ & $\begin{array}{l}-0.414 * * * \\
(0.103)\end{array}$ & $\begin{array}{l}-0.076 * * * \\
(0.026)\end{array}$ & $\begin{array}{l}-138.688^{* *} \\
(68.913)\end{array}$ \\
\hline $\begin{array}{l}\text { County level controls } \\
\text { Observations } \\
R \text {-sq. }\end{array}$ & $\begin{array}{l}\text { Yes } \\
672 \\
0.109\end{array}$ & $\begin{array}{l}\text { Yes } \\
672 \\
0.045\end{array}$ & $\begin{array}{l}\text { Yes } \\
672 \\
0.256\end{array}$ & $\begin{array}{l}\text { Yes } \\
672 \\
0.093\end{array}$ & $\begin{array}{l}\text { Yes } \\
690 \\
0.130\end{array}$ & $\begin{array}{l}\text { Yes } \\
690 \\
0.238\end{array}$ & $\begin{array}{l}\text { Yes } \\
690 \\
0.124\end{array}$ \\
\hline
\end{tabular}


Table 9

\section{Impact on the Real Economy}

This table examines the effect at the county level on the real economy. County exposure is measured as the deposit-weighted average, across banks, of the real estate exposure of banks in each county. The main variable of interest, Exposed County, is equal to 1 if the county lies in the top quartile of this distribution. In Panel A, all dependent variables are changes from 2007 to 2009. In Panel B, the dependent variables are changes from 2007 to 2014 , apart from the last column which is 2007 to 2013 . All specifications include county controls. The analysis is constrained to counties that did not experience a real estate drop. $* * *$, $* *$, and $*$ indicate statistical significance at the 1\%, 5\%, and 10\% level, respectively.

\begin{tabular}{|c|c|c|c|c|c|c|}
\hline Dependent variable: & $\begin{array}{l}\% \Delta \\
\text { Employment } \\
\text { (1) }\end{array}$ & $\begin{array}{l}\% \Delta \text { Num of } \\
\text { Establishments } \\
\text { (2) }\end{array}$ & $\begin{array}{l}\% \Delta \text { Num of } \\
\text { Establishments, 1-19 } \\
\text { employees } \\
\text { (3) }\end{array}$ & $\begin{array}{l}\% \text { \% Num of } \\
\text { Establishments, } \\
\text { 20-49 employees } \\
\text { (4) }\end{array}$ & $\begin{array}{l}\% \Delta \text { Num of } \\
\text { Establishments, } \\
50+\text { employees } \\
\text { (7) }\end{array}$ & $\begin{array}{l}\text { Percent of Firm } \\
\text { Births }\end{array}$ \\
\hline Exposed county & $\begin{array}{l}-0.015^{* *} \\
(0.007)\end{array}$ & $\begin{array}{l}-0.009 * * \\
(0.004)\end{array}$ & $\begin{array}{l}-0.008^{* *} \\
(0.004)\end{array}$ & $\begin{array}{l}-0.021^{*} \\
(0.011)\end{array}$ & $\begin{array}{l}-0.003 \\
(0.014)\end{array}$ & $\begin{array}{l}-0.010^{* * *} \\
(0.004)\end{array}$ \\
\hline $\begin{array}{l}\text { County level controls } \\
\text { Observations } \\
R \text {-sq. }\end{array}$ & $\begin{array}{l}\text { Yes } \\
716 \\
0.136 \\
\end{array}$ & $\begin{array}{l}\text { Yes } \\
716 \\
0.149 \\
\end{array}$ & $\begin{array}{l}\text { Yes } \\
716 \\
0.119 \\
\end{array}$ & $\begin{array}{l}\text { Yes } \\
716 \\
0.117 \\
\end{array}$ & $\begin{array}{l}\text { Yes } \\
716 \\
0.033 \\
\end{array}$ & $\begin{array}{l}\text { Yes } \\
715 \\
0.383 \\
\end{array}$ \\
\hline \multicolumn{7}{|l|}{ Panel B: 2007 to 2014} \\
\hline Dependent variable: & $\begin{array}{l}\text { \% } \Delta \\
\text { Employment } \\
(1) \\
\end{array}$ & $\begin{array}{l}\% \Delta \text { Num of } \\
\text { Establishments } \\
\text { (2) }\end{array}$ & $\begin{array}{l}\% \Delta \text { Num of } \\
\text { Establishments, 1-19 } \\
\text { employees } \\
\text { (3) }\end{array}$ & $\begin{array}{l}\% \Delta \text { Num of } \\
\text { Establishments, } \\
20-49 \text { employees } \\
\text { (4) }\end{array}$ & $\begin{array}{l}\text { \% } \Delta \text { Num of } \\
\text { Establishments, } \\
50+\text { employees } \\
(7)\end{array}$ & $\begin{array}{l}\text { Percent of Firm } \\
\text { Births }\end{array}$ \\
\hline Exposed county & $\begin{array}{l}0.003 \\
(0.011)\end{array}$ & $\begin{array}{l}-0.015^{* *} \\
(0.007)\end{array}$ & $\begin{array}{l}-0.018^{* * *} \\
(0.007)\end{array}$ & $\begin{array}{l}0.008 \\
(0.015)\end{array}$ & $\begin{array}{l}0.017 \\
(0.019)\end{array}$ & $\begin{array}{l}-0.029 * * * \\
(0.010)\end{array}$ \\
\hline County level controls & Yes & Yes & Yes & Yes & Yes & Yes \\
\hline Observations & 715 & 715 & 715 & 715 & 715 & 715 \\
\hline$R$-sq. & 0.175 & 0.292 & 0.283 & 0.081 & 0.107 & 0.466 \\
\hline
\end{tabular}




\section{Internet Appendix}

Figure A1

\section{The Effect of the Regulation on Small Business Lending}

This figure plots the small business originations of banks with between $\$ 10$ billion and $\$ 100$ billion in assets and those with more than $\$ 100$ billion in assets. There does not seem to be a change in small business originations around the time the Dodd-Frank Act came into effect.

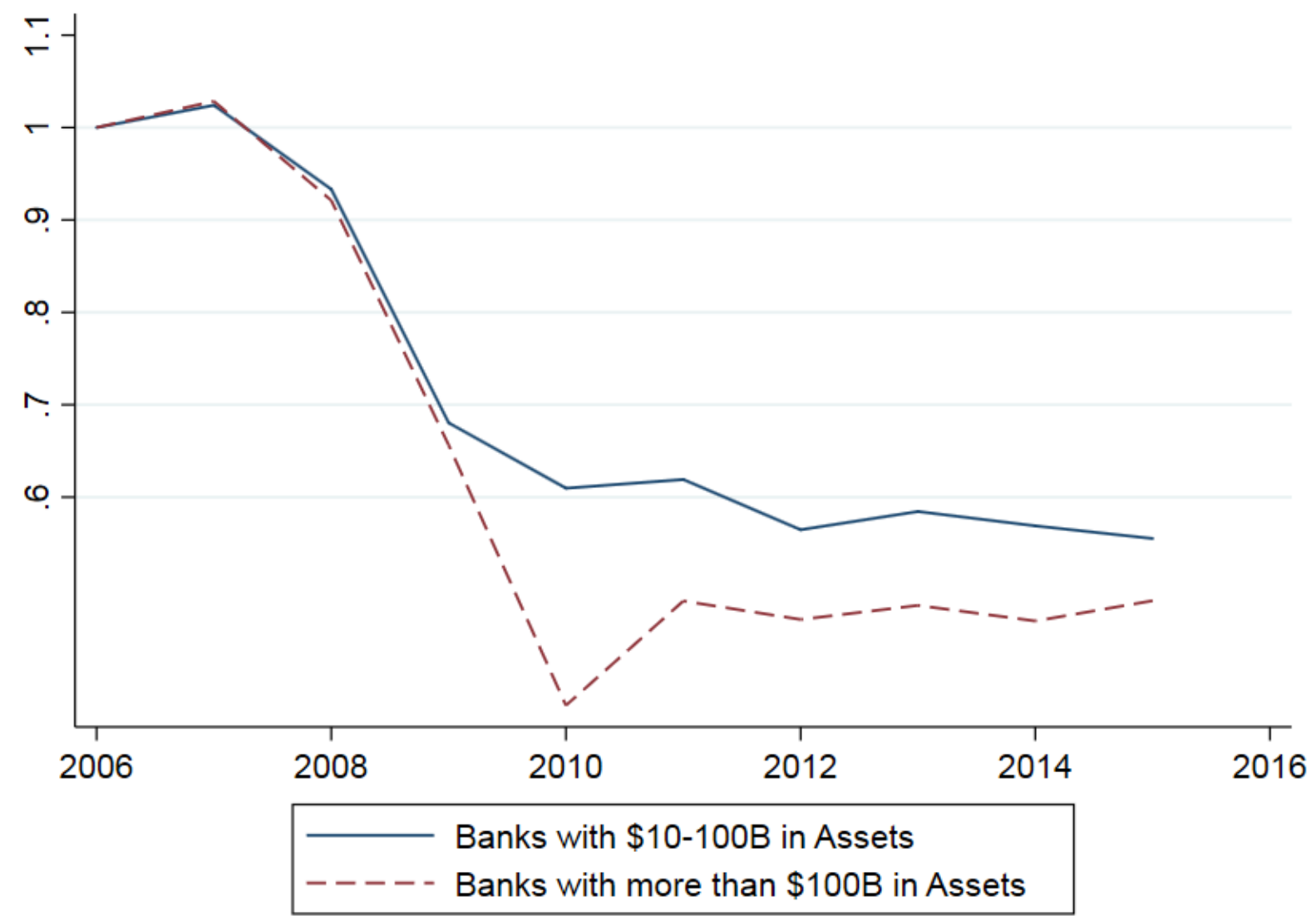




\section{Table A1}

\section{Entry into New Counties, excluding M\&A activity}

The dependent variable is equal to 1 if the bank entered the county between June 2006 and June 2008, and a probit is estimated. In all specifications, the coefficients reported are marginal effects. Standard errors (reported in brackets) are clustered at the bank level. ***, **, and * indicate statistical significance at the $1 \%, 5 \%$, and $10 \%$ level, respectively.

\begin{tabular}{|c|c|c|c|c|}
\hline & $(1)$ & $(2)$ & (3) & $(4)$ \\
\hline Healthy bank & $\begin{array}{l}0.317^{* *} \\
(0.126)\end{array}$ & $\begin{array}{l}0.804 * * \\
(0.327)\end{array}$ & $\begin{array}{l}0.061 \\
(0.190)\end{array}$ & $\begin{array}{l}-0.150 \\
(0.261)\end{array}$ \\
\hline - Log (Number of new banks, 1996-2005) & -- & $\begin{array}{l}0.379 * * \\
* \\
(0.143)\end{array}$ & -- & -- \\
\hline $\begin{array}{l}\text { Healthy bank } x \text {-Log (Number of new } \\
\text { banks) }\end{array}$ & -- & $\begin{array}{l}0.215^{*} \\
(0.129)\end{array}$ & -- & -- \\
\hline Deposits HHI (2006) & -- & -- & $\begin{array}{l}-0.103 \\
(0.071)\end{array}$ & -- \\
\hline Healthy bank $\mathrm{x}$ Deposits HHI & -- & -- & $\begin{array}{l}0.124 * \\
(0.074)\end{array}$ & -- \\
\hline Rice and Strahan (2010) index & -- & -- & -- & $\begin{array}{l}- \\
0.251 * * \\
(0.121)\end{array}$ \\
\hline Healthy bank $\mathrm{x}_{\mathrm{i}}$ Rice-Strahan index & -- & -- & -- & $\begin{array}{l}0.303^{* *} \\
(0.141)\end{array}$ \\
\hline Bank Controls & Yes & Yes & Yes & Yes \\
\hline County level controls (as in Panel A) & Yes & Yes & Yes & Yes \\
\hline Observations & 6415 & 6415 & 6415 & 1407 \\
\hline$R$-sq. & 0.075 & 0.082 & 0.079 & 0.191 \\
\hline Marginal Effect of Healthy Bank & $\begin{array}{l}0.016 * * * \\
(0.006)\end{array}$ & $\begin{array}{l}0.018^{* *} \\
(0.006)\end{array}$ & $\begin{array}{l}0.017^{* *} \\
(0.006)\end{array}$ & $\begin{array}{l}0.001^{*} \\
(0.006)\end{array}$ \\
\hline
\end{tabular}




\section{Table A2}

\section{Change in Deposit Rates, 2008 vs. 2006}

This table compares the change in deposit rates from 2006 to 2008 for healthy banks and for exposed banks. In Panel A, the dependent variable is the change in the deposit rate for a $\$ 10,000$ balance in a money market account (specification (1)), 3 Month CD (Specification (2)), 12 Month CD (Specification (3)), and 5 Year CD (Specification (4)). In panel B, the dependent variable is deposit rate for a $\$ 100,000$ balance in each of those accounts. Both panels include Standard errors (reported in brackets) are clustered at the bank level. The dependent variables are in percent. $* * *, * *$, and $*$ indicate statistical significance at the $1 \%, 5 \%$, and $10 \%$ level, respectively.

Panel A: Account with $\$ 10,000$ balance

\begin{tabular}{lllll}
\hline Dependent variable: & \multicolumn{4}{c}{ Change in the deposit rate: } \\
\cline { 2 - 5 } & $\begin{array}{l}\text { Money } \\
\text { market } \\
(1)\end{array}$ & $\begin{array}{l}\text { 3-month } \\
\text { CD }\end{array}$ & $\begin{array}{l}\text { 12-month } \\
\text { CD } \\
(2)\end{array}$ & $\begin{array}{l}\text { 5-year } \\
\text { CD } \\
(3)\end{array}$ \\
\hline \multirow{2}{*}{ Healthy bank } & -0.185 & 0.040 & 0.204 & -0.251 \\
& $(0.197)$ & $(0.221)$ & $(0.262)$ & $(0.236)$ \\
Bank Controls: & Yes & Yes & Yes & Yes \\
Fixed effect: County & Yes & Yes & Yes & Yes \\
Observations & 1,423 & 1,415 & 1,427 & 1,370 \\
$R$-sq. & 0.400 & 0.503 & 0.433 & 0.482 \\
\hline
\end{tabular}

Panel B: Account with $\$ 100,000$ balance

\begin{tabular}{lllll}
\hline Dependent variable: & \multicolumn{4}{c}{ Change in the deposit rate: } \\
\cline { 2 - 5 } & $\begin{array}{l}\text { Money } \\
\text { market } \\
(1)\end{array}$ & $\begin{array}{l}\text { 3-month } \\
\text { CD } \\
(2)\end{array}$ & $\begin{array}{l}\text { 12-month } \\
\text { CD } \\
(3)\end{array}$ & $\begin{array}{l}\text { 5-year } \\
\text { CD } \\
(4)\end{array}$ \\
\hline \multirow{2}{*}{ Healthy bank } & $-0.404^{*}$ & $-0.412^{*}$ & -0.084 & -0.176 \\
& $(0.238)$ & $(0.221)$ & $(0.200)$ & $(0.278)$ \\
Bank Controls: & & & & \\
Fixed effect: County & Yes & Yes & Yes & Yes \\
Observations & Yes & Yes & Yes & Yes \\
$R$-sq. & 1,423 & 1,415 & 1,427 & 1,370 \\
\hline
\end{tabular}

